\title{
Mapping deep peat carbon stock from a LiDAR based DTM and field measurements, with application to eastern Sumatra
}

\author{
Ronald Vernimmen ${ }^{1,2^{*}} \mathbb{0}$, Aljosja Hooijer ${ }^{1}$, Rizka Akmalia' ${ }^{1}$, Natan Fitranatanegara' ${ }^{1}$, Dedi Mulyadi ${ }^{1,3}$,
} Angga Yuherdha ${ }^{1}$ (D) , Heri Andreas ${ }^{4}$ and Susan Page ${ }^{5}$ (D)

\begin{abstract}
Background: Reduction of carbon emissions from peatlands is recognized as an important factor in global climate change mitigation. Within the SE Asia region, areas of deeper peat present the greatest carbon stocks, and therefore the greatest potential for future carbon emissions from degradation and fire. They also support most of the remaining lowland swamp forest and its associated biodiversity. Accurate maps of deep peat are central to providing correct estimates of peat carbon stocks and to facilitating appropriate management interventions. We present a rapid and cost-effective approach to peat thickness mapping in raised peat bogs that applies a model of peat bottom elevation based on field measurements subtracted from a surface elevation model created from airborne LiDAR data.

Results: In two raised peat bog test areas in Indonesia, we find that field peat thickness measurements correlate well with surface elevation derived from airborne LiDAR based DTMs $\left(R^{2} 0.83-0.88\right)$, confirming that the peat bottom is often relatively flat. On this basis, we created a map of extent and depth of deep peat $(>3 \mathrm{~m}$ ) from a new DTM that covers two-thirds of Sumatran peatlands, applying a flat peat bottom of $0.61 \mathrm{~m}+\mathrm{MSL}$ determined from the average of 2446 field measurements. A deep peat area coverage of $2.6 \mathrm{Mha}$ or $60.1 \%$ of the total peat area in eastern Sumatra is mapped, suggesting that deep peat in this region is more common than shallow peat and its extent was underestimated in earlier maps. The associated deep peat carbon stock range is 9.0-11.5 Pg C in eastern Sumatra alone.
\end{abstract}

Conclusion: We discuss how the deep peat map may be used to identify priority areas for peat and forest conservation and thereby help prevent major potential future carbon emissions and support the safeguarding of the remaining forest and biodiversity. We propose rapid application of this method to other coastal raised bog peatland areas in SE Asia in support of improved peatland zoning and management. We demonstrate that the upcoming global ICESat-2 and GEDI satellite LiDAR coverage will likely result in a global DTM that, within a few years, will be sufficiently accurate for this application.

Keywords: Below-ground carbon stock, Peat, Peat thickness, Lowland, Sumatra, LiDAR, ICESat-2 DTM

*Correspondence: ronald.vernimmen@gmail.com

2 Present Address: Data for Sustainability, 4571 AK Axel, The Netherlands

Full list of author information is available at the end of the article

\begin{abstract}
Background
Coastal peatlands cover some $10 \%$ of the land area in much of SE Asia and are subject to a range of environmental issues following deforestation and drainage in recent decades, including peat oxidation and fires that
\end{abstract}

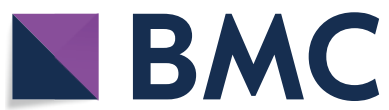

(c) The Author(s) 2020. This article is licensed under a Creative Commons Attribution 4.0 International License, which permits use, sharing, adaptation, distribution and reproduction in any medium or format, as long as you give appropriate credit to the original author(s) and the source, provide a link to the Creative Commons licence, and indicate if changes were made. The images or other third party material in this article are included in the article's Creative Commons licence, unless indicated otherwise in a credit line to the material. If material is not included in the article's Creative Commons licence and your intended use is not permitted by statutory regulation or exceeds the permitted use, you will need to obtain permission directly from the copyright holder. To view a copy of this licence, visit http://creativeco mmons.org/licenses/by/4.0/. The Creative Commons Public Domain Dedication waiver (http://creativecommons.org/publicdomain/ zero/1.0/) applies to the data made available in this article, unless otherwise stated in a credit line to the data. 
result in haze and major carbon emissions [1-5], biodiversity loss [6-9], and increased flooding risk following land subsidence [10-12]. Reducing carbon emissions from peatlands in this region has been recognized as a key factor in reducing global peatland emissions, aiming to mitigate climate change $[1,13,14]$.

Peat consists of partially decomposed plant material, which will accumulate when net primary production exceeds the rate of decomposition. In temperate and boreal climates where most peat occurs [15], decomposition is inhibited by anaerobic conditions [16] and cold temperatures [17]. In the tropics decomposition is inhibited by anaerobic conditions [18] and more recalcitrant organic matter $[13,19,20]$. While large areas of tropical peat are also found in South America and Central Africa [2, 21-23], SE Asia hosts an estimated 38\% of both tropical peat area and volume [24]. Indonesia is the country with the most tropical peat with estimates of below-ground carbon stock ranging between 28.1 and 57.4 Pg C $[2,25,26]$.

Since peat is mostly water $(80->90 \%)$ and organic matter (of which some $51-56 \%$ is carbon; $[2,27,28]$ ), it is not a stable material like most other soils that have a high mineral content. When dried, peat shrinks, oxidizes and can easily burn. Shrinkage and oxidation as well as peat combustion result in land surface subsidence [2936] that often results in flooding (e.g. [37-40]). In much of the world, remaining intact peatlands have therefore been protected, and drained peatlands are being carefully managed and, in some cases, restored, to mitigate these impacts (e.g. [41]).

In Indonesia, peatlands in their natural state are covered by tropical rainforest with very high biodiversity [42, 43]. Limited access and poor conditions for agriculture and road construction have long kept these areas undisturbed by human activities. Peat of depths over $2 \mathrm{~m}$ was considered unsuitable for development until the 1990s [44-46] and was protected by Indonesian law. However, since then, extensive areas of peatland, including those with peat exceeding a thickness of $3 \mathrm{~m}$, have been deforested and drained at a rapid rate, with only $29.1 \%$ of peatland in Sumatra and Kalimantan remaining forested by early 2015 and only $6.5 \%$ classed as undisturbed primary forest [47]. A further major reduction in peatland forest cover occurred during late 2015 when an estimated 0.7 to $1.2 \mathrm{Mha}$ of peatland in Sumatra and Kalimantan were burnt $[48,49]$.

Following the devastating fires of recent years, especially 2014 [4] and 2015 [5], the Indonesian Government and some plantation companies have made efforts to limit the deforestation and drainage of peatland, and to raise water levels in some peatlands that burnt in 2015 [50]. This may provide an opportunity to prevent further peat loss and conserve the limited areas of remaining peat swamp forest. However, this will require conservation zoning based on reliable peat thickness maps. Existing peat thickness maps for Indonesia are inaccurate [26, 51] and in some areas contested. The Indonesian Peat Prize process was started to improve maps [52] but creating such a map to a level of accuracy that suits all purposes will likely take some years.

For land use planning at the landscape scale, accuracy requirements in peat thickness mapping are lower than for detailed management plans at the plot scale. For identification of peatland areas in Indonesia most urgently requiring conservation (where forest is still present) or restoration (where peatland is already cleared of forest and drained), it may be sufficient to prioritize locations where the peat is over $3 \mathrm{~m}$ in thickness and presents the highest carbon stock per unit area. Furthermore, several Indonesian regulatory and policy measures at the national, sectoral and local levels require deep peat $(>3 \mathrm{~m})$ to be protected and conserved. For an overview of these regulations see [53]. It is also the deeper peat areas that support any remaining peat swamp forest; hence in these situations, both high carbon stock and high biodiversity can be prioritized. This is not to say that shallower peats $(<3 \mathrm{~m})$ do not play a role in carbon storage and release, but in Indonesia most shallow peats have been subject to a more intense degree of land use pressure and most are under some form of agriculture. These highly modified and degraded peats would require a much greater range of interventions (ecological and socio-economic) to bring about successful restoration outcomes.

In this paper, we present a model of peat cover and thickness for the deep peat $(>3 \mathrm{~m})$ areas of the eastern Sumatra lowlands. The four objectives of the study are (i) to present a method to model extent and thickness of deep peat $(>3 \mathrm{~m}$ ) for the study region using a LiDARbased DTM (ii) to validate the accuracy of the model using field measurements; (iii) to use the map of deep peat to calculate peat carbon stocks and to highlight priority locations for peatland and forest protection; and (iv) to investigate whether such assessment is possible with the satellite LiDAR data that is now becoming available globally.

\section{Methods}

\section{Study area}

The study focuses on the eastern Sumatra lowland that has the largest mapped concentration of peatland in Indonesia [54, 55], at 5.7 Mha in the Provinces of Riau, Jambi and South Sumatra alone [56]. Peatlands in this area have been subject to especially high rates of deforestation and plantation development since 2000 [57, 58], but still host some large protected peat swamp 
forest areas, such as the Giam Siak Kecil-Bukit Batu Biosphere Reserve, Kerumutan Wildlife Reserve and Berbak and Sembilang National Parks [59]. While Sembilang National Park is mostly dominated by mangrove forests without large peat domes, it does contain smaller domes and borders Berbak National Park, both host peat swamp forest [60]. Indonesian national and local governments and several major plantation companies that are active in this region have developed peat swamp forest conservation programs [61-68] that will benefit from reliable maps of peat and forest conditions. We also included a small area at 10-40 km from the coast in West Kaliman$\tan$, Kubu Raya, in this study, to demonstrate the broader validity of the methods beyond Sumatra.

\section{DTMs from airborne LiDAR data}

We applied a DTM created from airborne LiDAR data for eastern Sumatra [69] and for the Kubu Raya validation area in West Kalimantan [70], with an estimated overall vertical accuracy between 0.25 and $0.61 \mathrm{~m}$ [69].

\section{Peat thickness field measurements collected in validation areas}

Field surveys conducted in 2017 in the Bengkalis (54,133 ha) and Kubu Raya (23,681 ha) method validation areas applied a high accuracy survey protocol [70, 71]. Peat thickness, i.e. an organic top soil horizon of over $0.5 \mathrm{~m}$ thickness, was measured (Fig. 1) by surveyor teams using Edelman type augers, along straight line transects perpendicular to rivers, streams and sometimes canals and going up the peat dome slopes. Measurements were replicated at least twice at $5 \mathrm{~m}$ distance, until the difference between peat thickness values was less than $1 \mathrm{~m}$, with the interface between the peat and underlying mineral soil being photographed for later verification. The average value derived from approved measurements was used in further analyses.

\section{Measuring peat bottom elevation relative to mean sea level}

The peat thickness measured in the field was subtracted from the DTM surface elevation to obtain the peat bottom level, i.e. the interface between the peat and the underlying mineral sediment, at the measurement location, for all peat thickness measurements considered in this study.

\section{Creating peat thickness models}

Peat thickness models were created using airborne LiDAR based peat surface DTMs and average peat bottom levels derived from peat thickness field measurements. Peat thickness was determined as the difference

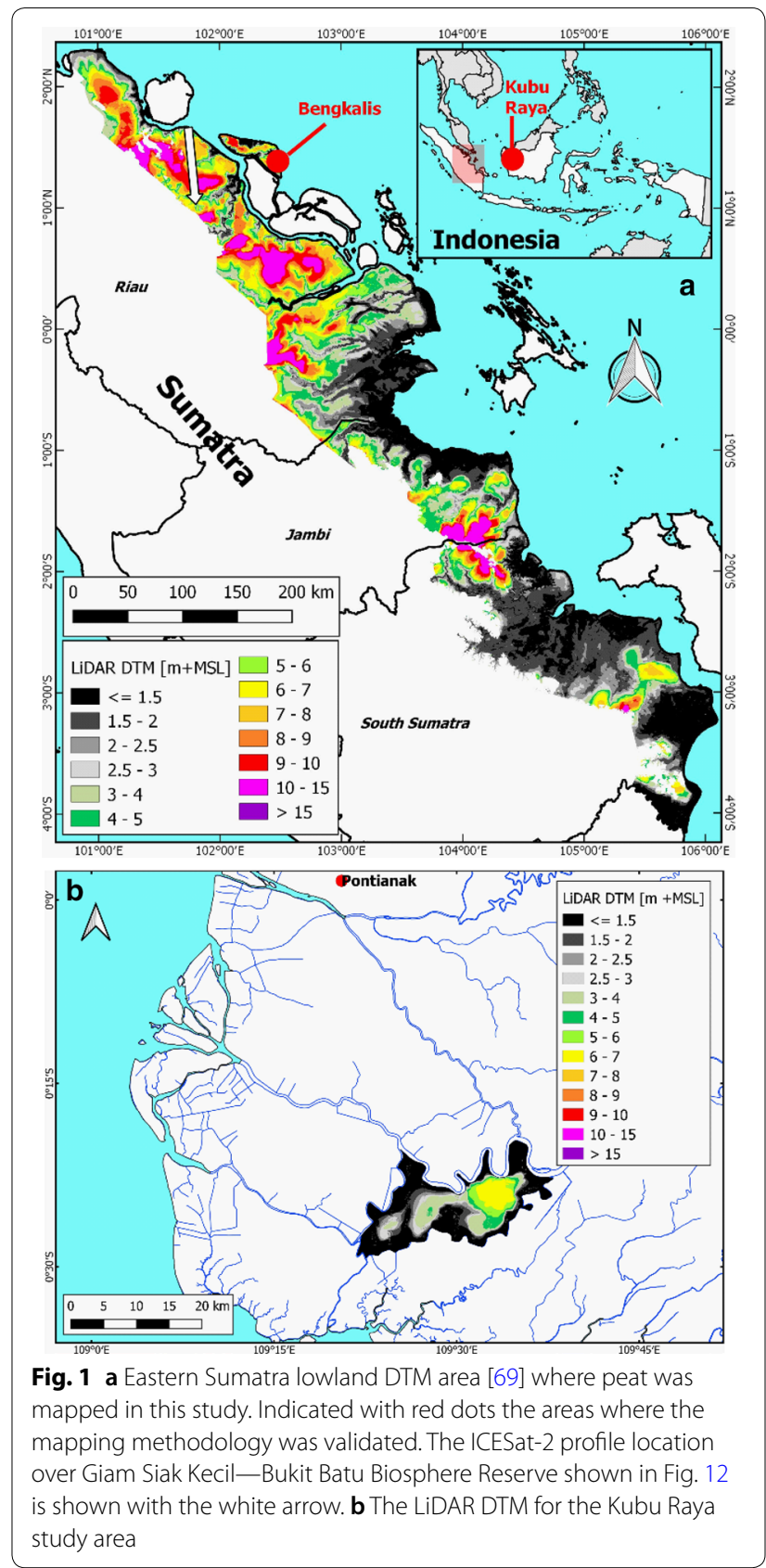

between peat surface and peat bottom, as illustrated in Fig. 2.

References [70, 71] demonstrated the application of three different peat mapping methods to two validation areas, Bengkalis in Riau (Sumatra) and Kubu Raya in West Kalimantan. The first method involved the creation of a peat bottom model by interpolation of a peat bottom surface model between measurement points and contours that were manually drawn and subtracting this model from the DTM. The second method assumed a 


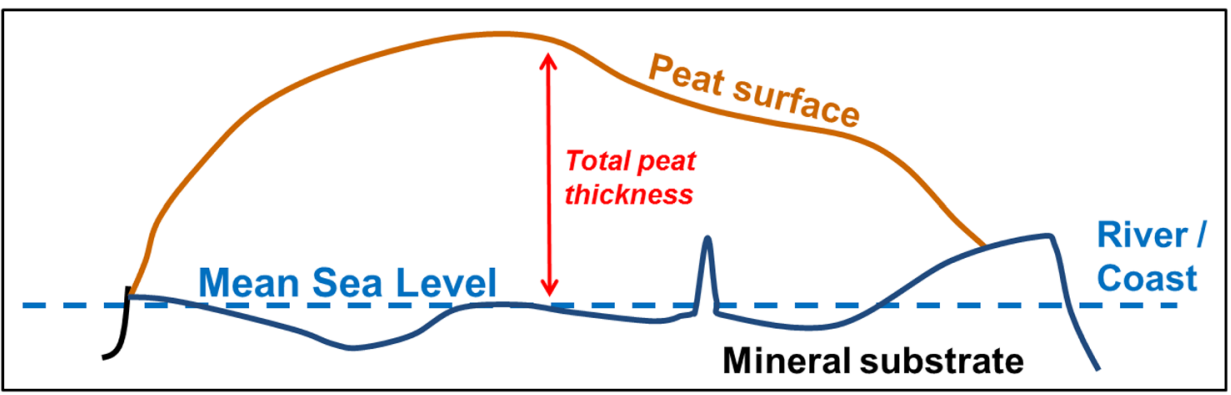

Fig. 2 Illustration of how peat thickness is determined as the difference between the peat surface and depth of the peat bottom (interface with the mineral substrate)

flat horizontal peat bottom surface determined from the average of available data, while the third method applied a regression equation between DTM and available peat thickness data. Considering that the three resulting peat thickness models were nearly identical $[70,71]$, the simplest method, assuming a flat horizontal peat bottom surface as determined from the average of available data, was applied in this study. The peat bottom level was subtracted from the peat surface elevation map to generate a peat thickness map.

\section{Mapping peat extent in validation areas}

Peat extent in the Bengkalis peat mapping method validation area was identified through visual interpretation of a composite Landsat-1 image of 5 October 1972 (i.e. when the area was still largely forested and peat extent could be discerned from vegetation patterns) [71] (Fig. 3). But whereas historical remote sensing imagery is often useful for visual interpretation of the peat extent from vegetation patterns, we found this not to be the case for the Kubu Raya area. Instead, we mapped the likely peat extent by applying the $2 \mathrm{~m}+\mathrm{MSL}$ contour line determined from the airborne LiDAR based DTM [70]. In

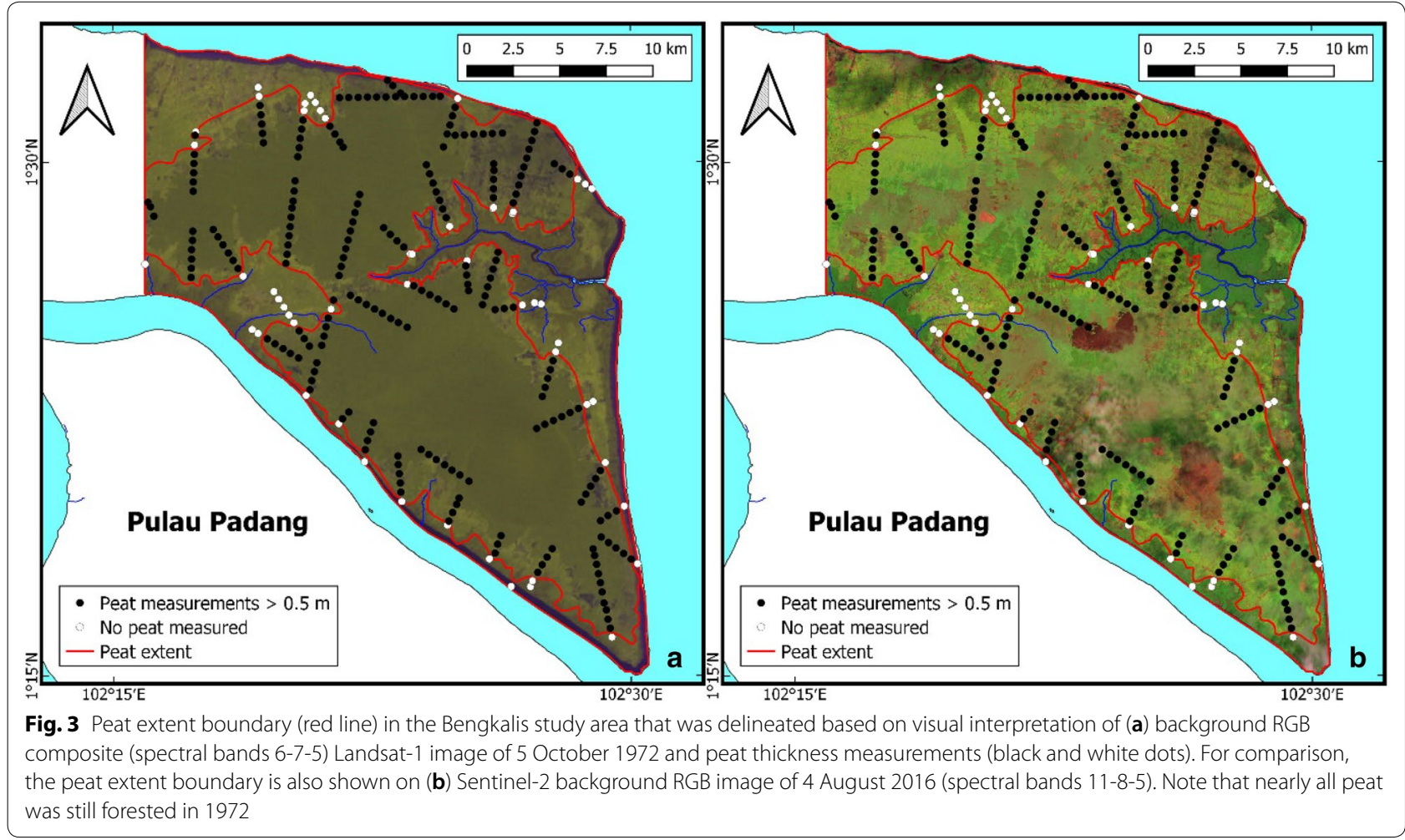


both areas the resulting peat extent was then further refined based on field measurements of peat presence and absence.

\section{Validating modelled peat thickness}

For the Bengkalis and Kubu Raya validation areas, peat thickness maps were created by subtracting a uniform peat bottom level from the DTM at $100 \mathrm{~m}$ spatial resolution. The uniform peat bottom was calculated as the average of peat bottom values determined from the DTM at $100 \mathrm{~m}$ spatial resolution and individual peat thickness measurements, for both areas separately. Peat thickness field measurements were then compared with modelled peat thickness at the same locations to determine the accuracy of the resulting peat thickness models. Average peat thickness for both models was calculated as the arithmetic mean of the modelled peat thickness for each of the individual $100 \mathrm{~m}$ grid cells.

\section{Estimating peat bottom elevation for eastern Sumatra}

From a larger database of existing field measurements [51], adding unpublished data from recent surveys, a set of 2446 measurements was extracted for peat $>3 \mathrm{~m}$ thickness, located within the maximum extent of deep peat as estimated in this study, and the arithmetic mean was calculated. $2198(89.9 \%)$ of the measurements were collected after 2010, and of the 2446 measurements, Riau had the most measurements 1587 (64.9\%), followed by South Sumatra and Jambi, with 487 (19.9\%) and 372 (15.2\%) measurements, respectively. The selected data were collected by 45 different sources between 2000 and 2017. It was found that in areas where multiple datasets were available for comparison, the data often showed considerable differences, especially for older data that were collected before GPS provided accurate locations. This illustrates the difficulty in conducting robust peat thickness surveys, at the large scale and under often difficult field conditions by sometimes untrained teams with often limited field supervision by experts, applying different protocols, and using different auger types [51]. Taken as a whole however, and excluding data collected before 2000, the compilation dataset does provide sufficient basis for estimating average peat bottom elevations over large areas.

\section{Creating a map of deep peat for eastern Sumatra}

Deep coastal peat (peat thickness $>3 \mathrm{~m}$ ) was mapped in the eastern Sumatra lowland within the available DTM extent (Fig. 1) and within the latest official peat extent as published by the Indonesian Ministry of Agriculture [56], excluding some smaller peat areas in river valleys surrounded by mineral uplands further inland where the peat bottom is expected to be no longer flat but sloping. Peat thickness was mapped by subtracting average peat bottom values determined from 2446 peat thickness measurements $>3 \mathrm{~m}$ from the DTM. Because this method was validated mostly with measurements of deep peat in Bengkalis and Kubu Raya, and is likely to be less reliable for areas of shallow peat, only peat thickness over $3 \mathrm{~m}$ is shown in the resulting peat maps and in carbon stock calculations presented here.

\section{Calculating deep peat carbon stocks}

The amount of carbon stored in a unit volume of peat was estimated by multiplying the bulk density (BD) by the carbon concentration (CC) of dry peat. Since BD and $\mathrm{CC}$ are known to spatially vary we have applied peat carbon density values ranging from 0.0545 to $0.0698 \mathrm{~g} \mathrm{~cm}^{-3}$, as derived for different Indonesian provinces from literature by [26], to determine a lower and upper limit of carbon stocks.

\section{Results}

Peat thickness models for validation areas

In total, a dataset of 508 field measurements (excluding replicates) was applied in peat mapping for the Bengkalis and Kubu Raya areas (Fig. 4). Of these, 399 were found to have peat $(>0.5 \mathrm{~m})$, and $53.1 \%(\mathrm{n}=270)$ had a peat thickness over $3 \mathrm{~m}$. Average peat thickness was $4.79 \mathrm{~m}$ $( \pm 2.17 \mathrm{~m}$ st. dev. $)$ and $3.45 \mathrm{~m}( \pm 1.60 \mathrm{~m}$ st. dev. $)$, respectively (Table 1 ).

High $R^{2}$ values of 0.83 and 0.88 between surface elevation and peat thickness were found for the Bengkalis and Kubu Raya study areas, respectively, with regression relations approaching unity (1:1) in both cases (Fig. 5). This confirms that the peat bottom is relatively flat and close to sea level, and that a DTM may be used for peat thickness mapping. In these areas the average position of the peat bottom was found to be 0.41 and $0.30 \mathrm{~m}+\mathrm{MSL}$ and the peat bottom was below $2 \mathrm{~m}+\mathrm{MSL}$ for almost all measurements ( 98.6 and $99.4 \%$ of measurements respectively) (Table 1).

When assuming a flat peat bottom throughout the two study areas, $82.2 \%(n=328)$ of the actual individual field measurements of peat bottom elevation were within $1 \mathrm{~m}$ above or below the average peat bottom of the two respective study areas and within $81.5 \%(\mathrm{n}=220)$ if only peat over $3 \mathrm{~m}$ thickness is considered (Table 1; Fig. 6). The overall RMSE is $0.89 \mathrm{~m}$ and $0.68 \mathrm{~m}$, for Bengkalis and Kubu Raya, respectively, and $0.87 \mathrm{~m}$ and $0.54 \mathrm{~m}$ if only peat over $3 \mathrm{~m}$ thickness is considered.

The resulting peat thickness models for the Bengkalis and Kubu Raya study areas, derived by applying average peat bottom values of 0.41 and $0.30 \mathrm{~m}+\mathrm{MSL}$, respectively, are shown in Fig. 7. Of the total peat area $(39,074$ ha or $72.2 \%$ and 10,763 ha or $45.5 \%$ of the 

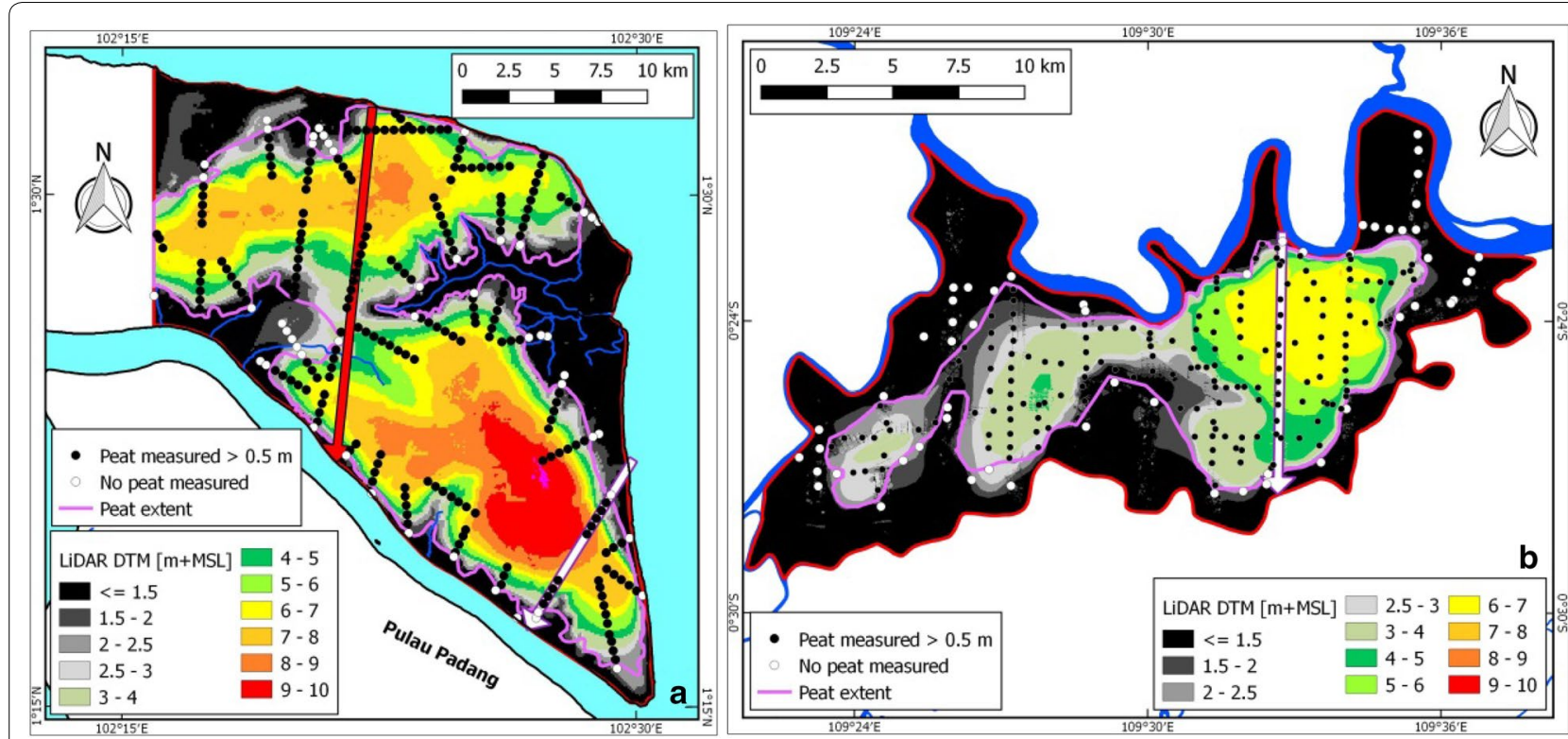

Fig. 4 Peat thickness measurement locations in Bengkalis (a) and Kubu Raya (b) study areas (red lines). In the background airborne LiDAR derived DTMs (Bengkalis: [71]; Kubu Raya: [70]). Locations of cross sections shown in Fig. 6 are indicated with white arrows. The ICESat-2 profile location over Bengkalis shown in Fig. 12 is shown with the red arrow

Table 1 Peat thickness (PT) measurement statistics for the Bengkalis and Kubu Raya study areas

\begin{tabular}{|c|c|c|}
\hline Statistic & Bengkalis & Kubu Raya \\
\hline Number of PT measurements $>0.5 \mathrm{~m}$ & 219 & 180 \\
\hline Number of PT measurements $>3 \mathrm{~m}$ & 170 & 100 \\
\hline Average PT $(\mathrm{m})$ & 4.79 & 3.45 \\
\hline Standard deviation PT (m) & 2.17 & 1.60 \\
\hline Average PB (m +MSL) & 0.41 & 0.30 \\
\hline Standard deviation PB (m) & 0.90 & 0.55 \\
\hline Number of PT measurements >0.5 m with PB below $0 \mathrm{~m}+\mathrm{MSL}(\%)$ & $81(37.0 \%)$ & $52(28.9 \%)$ \\
\hline Number of PT measurements $>0.5 \mathrm{~m}$ with PB below $1.5 \mathrm{~m}+\mathrm{MSL}(\%)$ & $198(90.4 \%)$ & $177(98.3 \%)$ \\
\hline Number of PT measurements >0.5 m with PB below 2 m_MSL (\%) & $216(98.6 \%)$ & $179(99.4 \%)$ \\
\hline Number of PT measurements $>0.5 \mathrm{~m}$ within $0.5 \mathrm{~m}$ of average PB (\%) & $72(32.9 \%)$ & $109(60.6 \%)$ \\
\hline Number of PT measurements $>0.5 \mathrm{~m}$ within $1 \mathrm{~m}$ of average PB (\%) & $160(73.1 \%)$ & $168(93.3 \%)$ \\
\hline Number of PT measurements $>3 \mathrm{~m}$ within $1 \mathrm{~m}$ of average PB (\%) & $128(75.3 \%)$ & $92(92.0 \%)$ \\
\hline
\end{tabular}

Each peat thickness value presents the average of 2 or more replicate measurements

$P B$ peat bottom

Bengkalis and Kubu Raya study areas, respectively), 80.5\% and 53.6\% has peat over $3 \mathrm{~m}$ in the Bengkalis and Kubu Raya study areas, respectively, and an overall average peat thickness of $5.39 \mathrm{~m}$ and $3.52 \mathrm{~m}$ for all peat or $6.26 \mathrm{~m}$ and $4.76 \mathrm{~m}$ for the peat area over $3 \mathrm{~m}$. Total peat volume was calculated to be $2.1 \mathrm{~km}^{3}$ and $0.38 \mathrm{~km}^{3}$ for Bengkalis and Kubu Raya, respectively, and $2.0 \mathrm{~km}^{3}$ and $0.27 \mathrm{~km}^{3}$ for peat over $3 \mathrm{~m}$.

\section{Measured peat thickness and peat bottom level for eastern} Sumatra

The compilation dataset of 2446 existing deep peat thickness measurements in eastern Sumatra yields an average peat thickness of $6.78 \mathrm{~m}( \pm 2.40 \mathrm{~m} \mathrm{st}$. dev. $)$ and an average peat bottom of $0.61 \mathrm{~m}( \pm 2.36 \mathrm{~m}$ st. dev.) + MSL, with $40.6 \%$ and $74.9 \%$ of measurements being below 0 and $2 \mathrm{~m}+$ MSL, respectively (Table 2; Fig. 8).

This confirms earlier reports of the peat bottom in tropical coastal peatlands usually being at or close to 

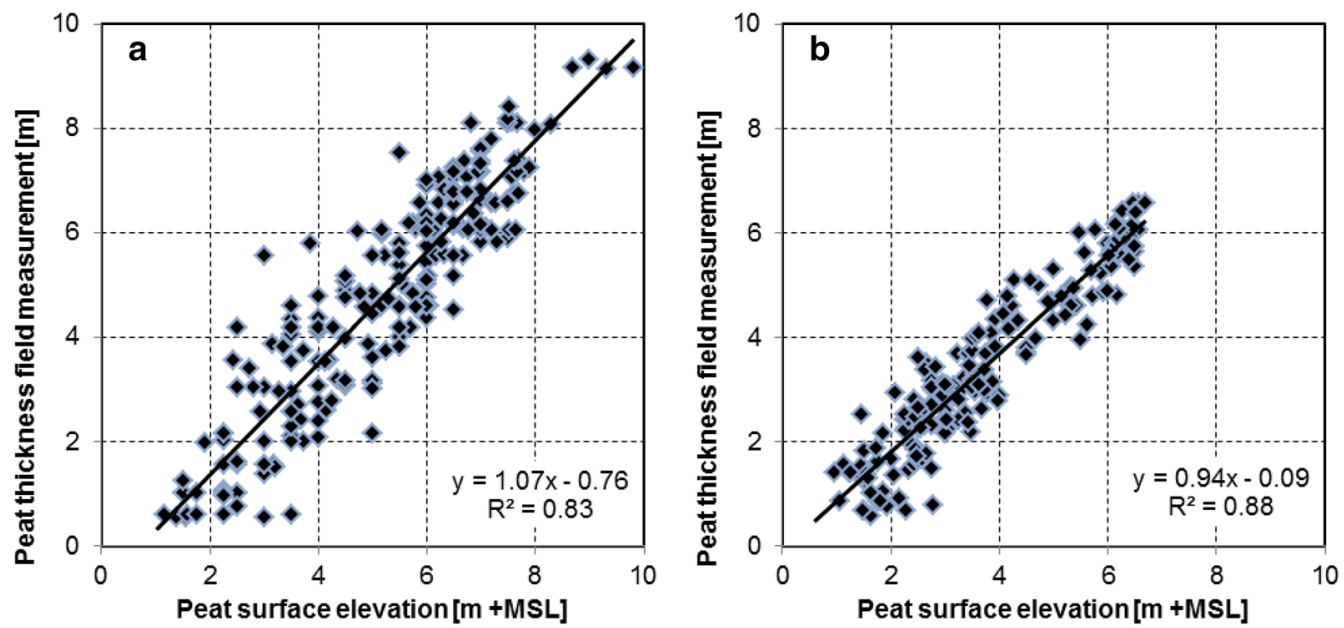

Fig. 5 Peat thickness measurements plotted against elevation as determined from the airborne LiDAR DTM for the $\mathbf{a}$ Bengkalis $(n=219)$ and $\mathbf{b}$ Kubu Raya $(n=180)$ study areas
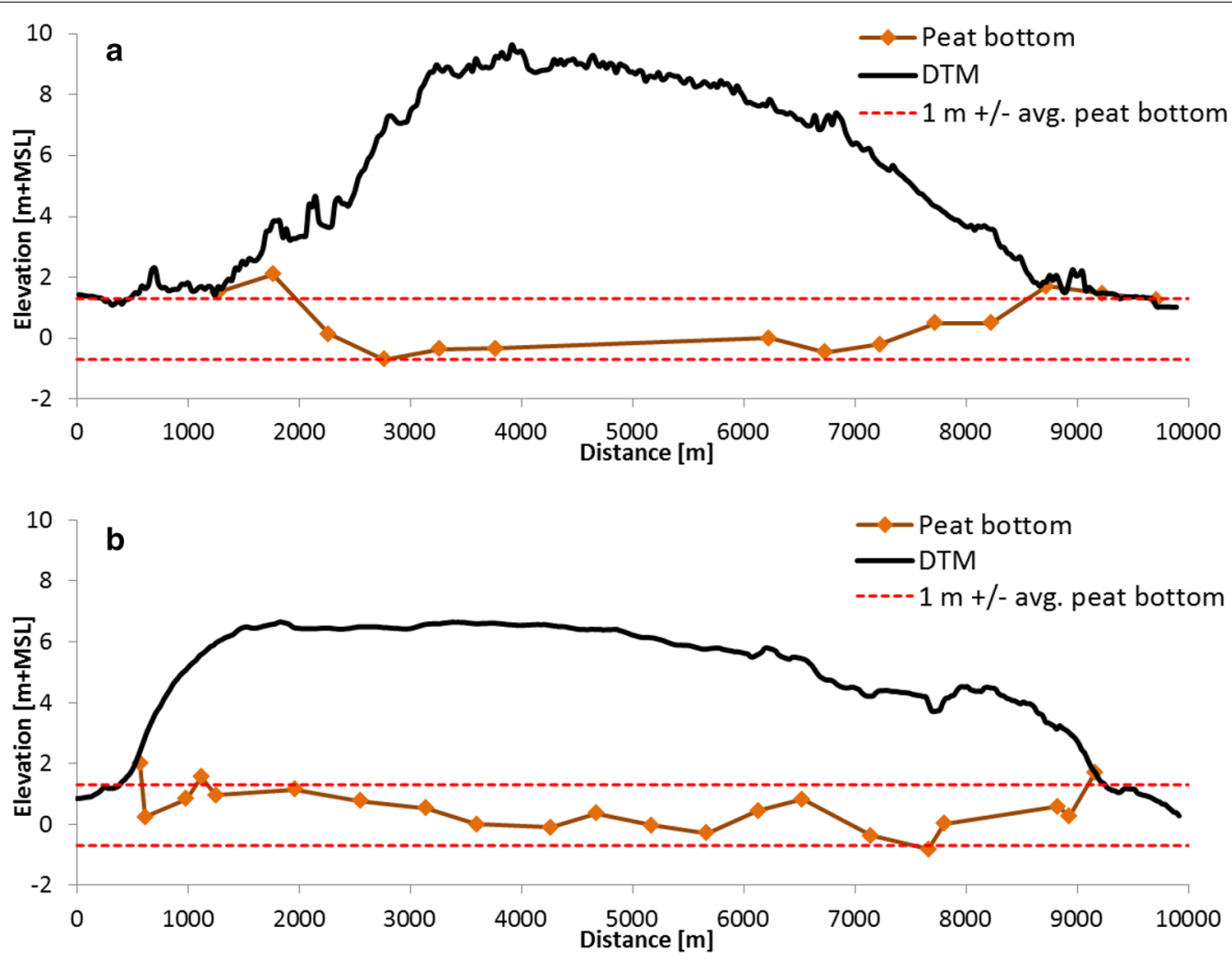

Fig. 6 Cross sections over the a Bengkalis and $\mathbf{b}$ Kubu Raya peat domes, showing LiDAR derived surface elevation (DTM) and the peat bottom as derived from field measurements. Locations of cross sections are shown in Fig. 4

sea level $[72,73]$ further supported by evidence shown in cross sections of peat domes in Sarawak [74-82], Riau [29] and Jambi [76, 83]. This is explained by coastal peat development in eastern Sumatra starting from river floodplains and mangroves some 6000 years ago $[54,79,84]$ on a nearly flat coastal plain $[84,85]$.

While there are regional differences in peat bottom (Table 2), we conclude that applying a flat peat bottom at 

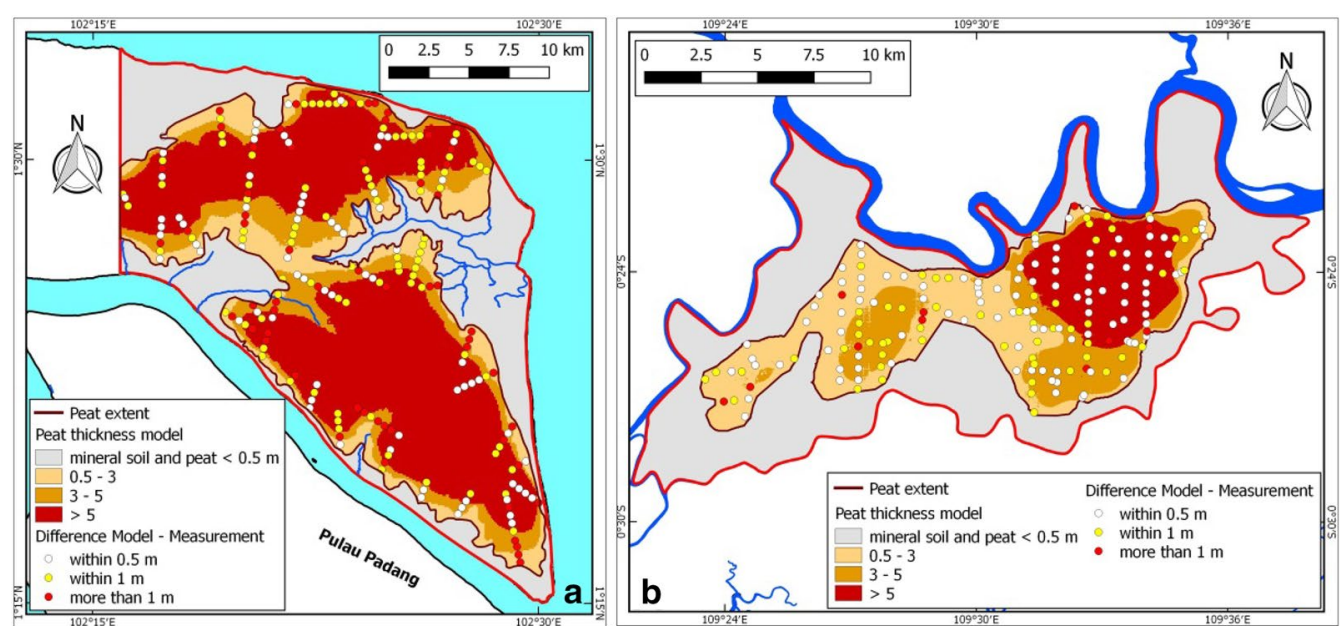

Fig. 7 Peat thickness models for a Bengkalis and $\mathbf{b}$ Kubu Raya as derived from airborne LiDAR based DTM and applying a constant peat bottom elevation of 0.41 and $0.30 \mathrm{~m}+\mathrm{MSL}$, respectively (Table 1). Peat thickness difference as calculated from the measurements and the peat thickness model is also shown

Table 2 Summary statistics of peat thickness (PT) measurements over $\mathbf{3} \mathbf{m}$ in eastern Sumatra lowland

\begin{tabular}{|c|c|c|c|c|c|c|c|c|}
\hline \multirow[t]{2}{*}{ Province } & \multirow{2}{*}{$\begin{array}{l}\text { No. } \\
\text { of measurements }\end{array}$} & \multirow[t]{2}{*}{ Avg. PT (m) } & \multirow[t]{2}{*}{ St. dev. PT (m) } & \multirow{2}{*}{$\begin{array}{l}\text { Avg. PB } \\
(\mathrm{m}+\mathrm{MSL})\end{array}$} & \multirow[t]{2}{*}{ St.dev. PB (m) } & \multicolumn{3}{|c|}{$\%$ of measurements with PB below } \\
\hline & & & & & & $0 \mathrm{~m}+\mathrm{MSL}$ & $1.5 \mathrm{~m}+\mathrm{MSL}$ & $2 m+M S L$ \\
\hline Riau & 1587 & 7.10 & 2.39 & 0.02 & 1.91 & 49.2 & 81.4 & 86.7 \\
\hline Jambi & 372 & 7.12 & 2.71 & 0.72 & 2.99 & 40.3 & 59.9 & 67.5 \\
\hline South Sumatra & 487 & 5.47 & 1.60 & 2.47 & 2.18 & 12.9 & 30.8 & 41.9 \\
\hline Total & 2446 & 6.78 & 2.40 & 0.61 & 2.36 & 40.6 & 68.1 & 74.9 \\
\hline
\end{tabular}

$P B$ peat bottom

the average value of $0.61 \mathrm{~m}+$ MSL yields the best approximation of likely peat thickness that is possible with the data available. Applying a peat bottom at 2 or $0 \mathrm{~m}+\mathrm{MSL}$ yields an estimate of minimum and maximum peat thickness, respectively.

\section{Deep peat map for eastern Sumatra}

The most likely deep peat extent for eastern Sumatra is presented in Fig. 9. The total modelled deep peat area in the eastern Sumatra lowlands ranges between 2.0 and 2.9 Mha, for the applied flat peat bottom range of 0 to $2 \mathrm{~m}+\mathrm{MSL}$, respectively. This equals $45.8 \%$ to $67.4 \%$ of the total probable peat extent (according to [56]) of 4.3 Mha that falls within the DTM study area. Applying the different regional most likely peat bottom values of $0.02,0.72$ and $2.47 \mathrm{~m}+$ MSL, for Riau, Jambi and South Sumatra, respectively, yields a deep peat extent of 2.6 Mha (Table 3). This deep peat extent is similar as when applying a most likely peat bottom value of $0.61 \mathrm{~m}$ $+\mathrm{MSL}$, which is the average of all measurements in Table 2. The 2.6 Mha mapped most likely deep extent is
$60.1 \%$ of the area mapped by [56], suggesting that deep peat is more common in this region than shallow peat, and far more extensive than the $33.0 \%$ reported by [56] for this same area. Recognizing that previously mapped peat extent is likely to be underestimated by some $10 \%$ $[25,51]$ we conservatively conclude that the area of deep peat in eastern Sumatra is roughly equal or somewhat larger than the area of peat of less than $3 \mathrm{~m}$ depth.

\section{Deep peat below-ground carbon stock map for the eastern Sumatra provinces}

The deep peat maps were used to calculate the belowground carbon stock in the eastern Sumatra study area. This yielded a minimum and maximum peat volume of 115.9 and $191.1 \mathrm{~km}^{3}$, assuming a peat bottom at 2 or $0 \mathrm{~m}$ + MSL respectively, and a most likely value of $165.2 \mathrm{~km}^{3}$ at a peat bottom of $0.61 \mathrm{~m}+$ MSL.

Applying a range in carbon density values of 0.0545 and $0.0698 \mathrm{~g} \mathrm{~cm}^{-3}$ to the deep peat maps, a total peat carbon stock range of 6.3 to $13.3 \mathrm{Pg}$ (applying a peat bottom of 2 or $0 \mathrm{~m}+\mathrm{MSL}$, respectively) was 


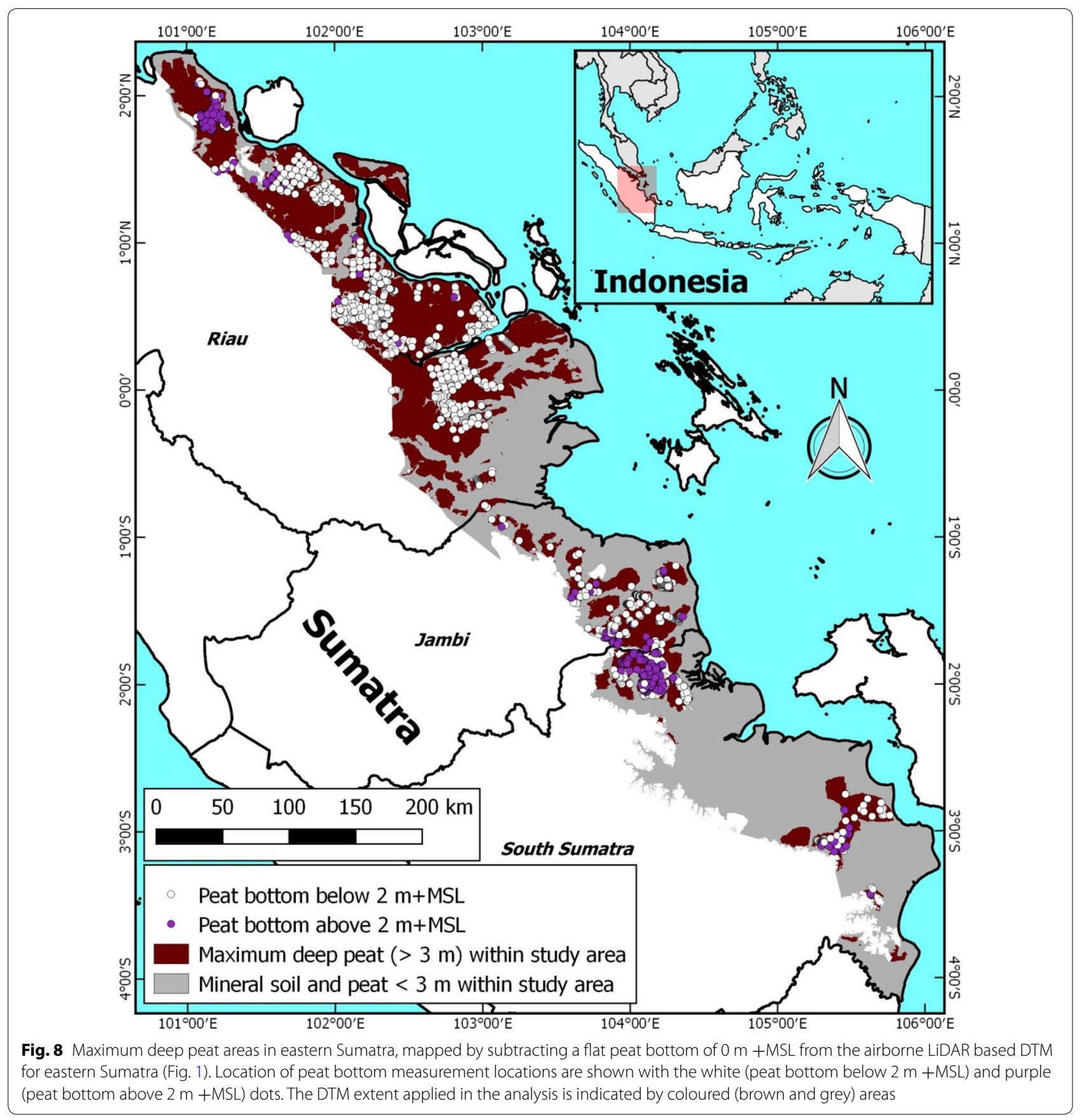

determined for the eastern Sumatra lowland area covered by the DTM, with a most likely range of 9.0-11.5 Pg (applying a peat bottom of $0.61 \mathrm{~m}+\mathrm{MSL}$ ). When applying a different most likely peat bottom value for each of the three provinces separately and spatially averaging the result based on deep peat extent in each of the three provinces, the total peat carbon stock ranged from 9.5 to $12.1 \mathrm{Pg}$, slightly higher than when applying an overall average peat bottom of $0.61 \mathrm{~m}$
+ MSL. Most of the deep peat carbon stock, i.e. $75.1 \%$, is found in Riau province, with a range of 7.7-9.9 Pg; Jambi and South Sumatra provinces follow at 12.8 (1.1-1.4 Pg C) and 10.6\% (0.59-0.75 Pg C), respectively (Table 3). 


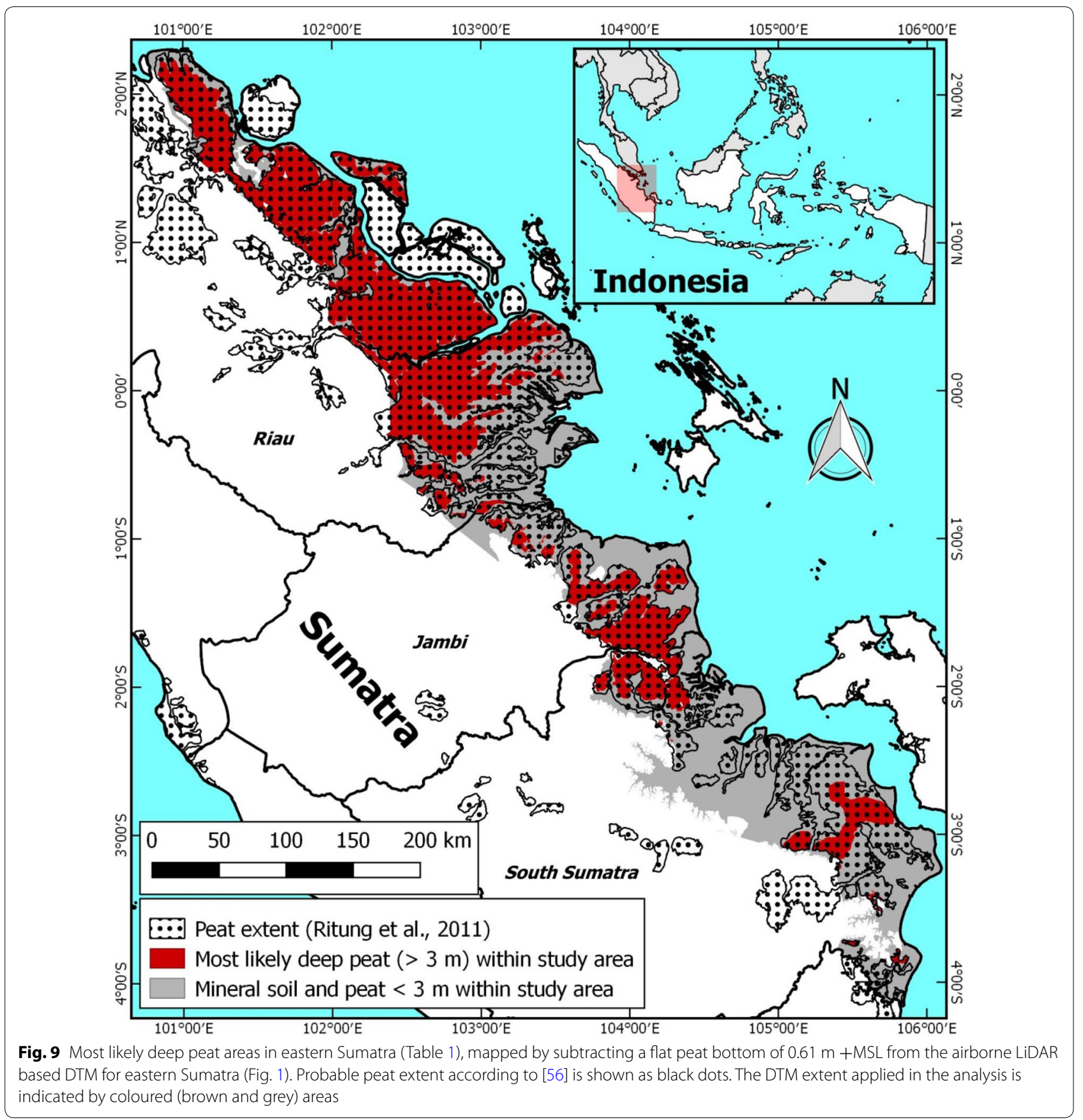

\section{Discussion}

The most likely deep peat area of 2.6 Mha identified for eastern Sumatra in this study (Table 3) constitutes 39.0\% and $17.2 \%$ of the total mapped Sumatra and Indonesia peatland area of 6.6 and $14.9 \mathrm{Mha}$, respectively [56]. If we assume that all remaining peat in Sumatra has a similar thickness distribution to that in the study area, with $60.1 \%$ of total peat area (4.3 Mha within the DTM extent of the study area) being deep peat, the total Sumatra deep peat area would be 3.9 Mha and the associated total Sumatra deep peat carbon stock would range between 13.9 and 17.8 Pg. This value is somewhat higher than the high end estimate of $11.9 \mathrm{Pg}$ as reported by [26] using the [56] peat map for both extent and depth (applying the high end of each depth range), for all peat in Sumatra including the shallow peat that we exclude in this study. Whilst we do not have further field data on peat thickness to support an assumption of equal deep peat distribution in other 
Table 3 Areas of modelled deep peat, average peat thickness (PT) and below-ground carbon stock in deep peat areas in eastern Sumatra lowland and breakdown per Province, assuming different peat bottom positions

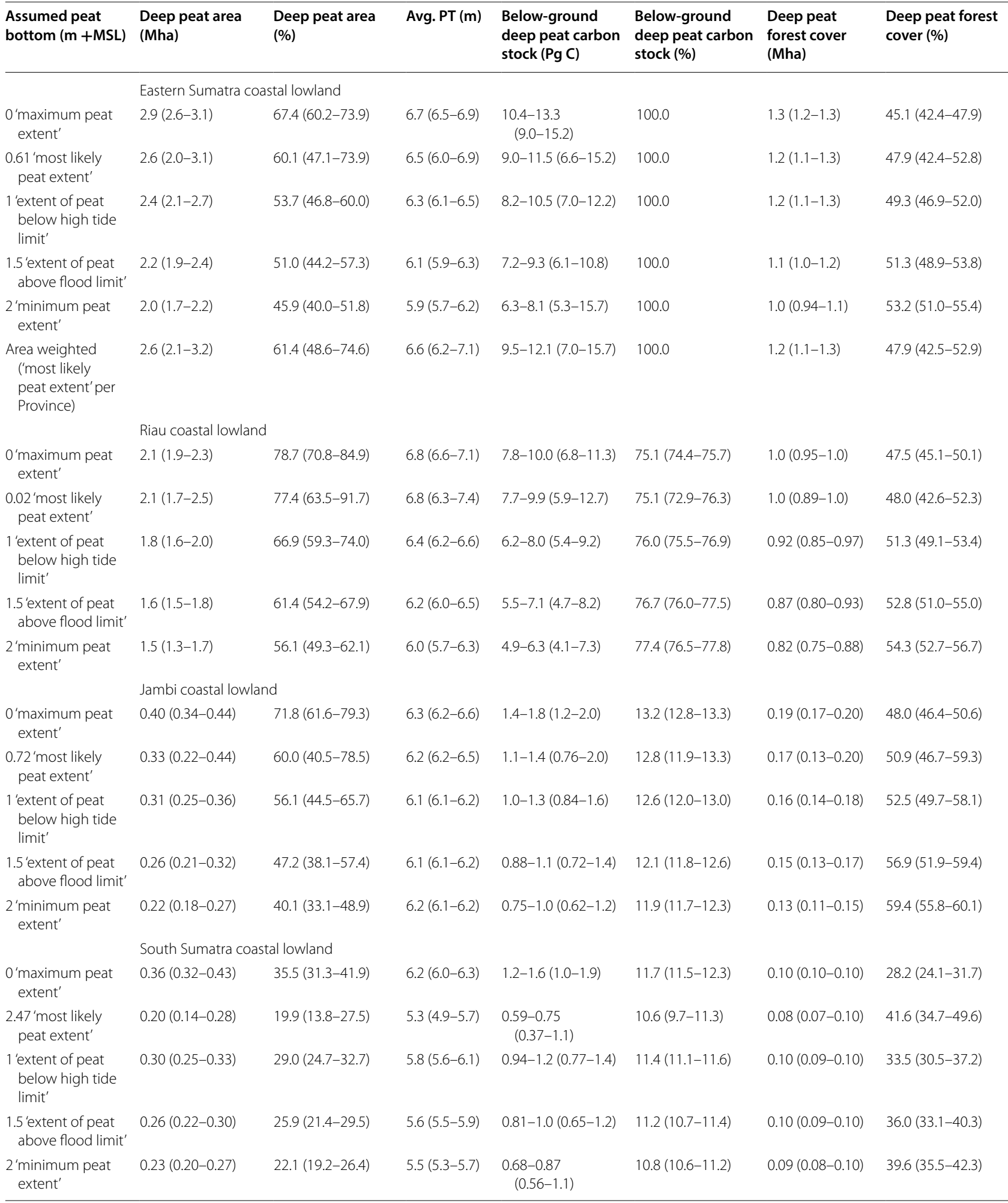

Below-ground deep peat carbon stock is calculated based on carbon densities ranging from 0.0545 and $0.0698 \mathrm{~g} \mathrm{~cm}^{-3}$. Deep peat forest cover in 2012 [86] and deep peat area extent relative to [56] are provided as well. Values in brackets provide range taking into account the accuracy of the DTM (RMSE 0.25-0.61 m; [69]) 
provinces, the distribution of deep peat ( $>3 \mathrm{~m}$ ) in [56] for the Riau, Jambi and South Sumatra provinces is, at $28.7 \%$ (1.7 Mha out of a total peat extent of $5.8 \mathrm{Mha}$ ), similar to the $26.7 \%$ (1.7 Mha out of 6.4 Mha) distribution of deep peat for all provinces in Sumatra combined [56] and as such we consider this a fair assumption. It is furthermore noted that by far the largest extent of deep peat in Sumatra is located in Riau province (93.7\% according to [56]), albeit that our area value of 2.1 Mha (Table 3) is some 0.5 Mha higher compared to [56] who mapped 1.6 Mha of deep peat. In addition, while not further mapped in this study, we note that shallow peat also plays a role in carbon storage and release.

Peat that is below the water table, both currently and in the future, will most likely not generate substantial carbon emissions from oxidation and therefore may be excluded from carbon stock calculations used in predicting future emissions [11, 71], although it is noted here that continued DOC loss and shoreline erosion are potential pathways for continued but slower carbon loss from inundated coastal peatlands [87]. In addition, sea water provides abundant sulphate and sulphate reduction that can oxidize organic matter in anaerobic environments [88]. The extent to which this would happen in Indonesian coastal peatlands subject to sea water incursion and inundation would, however, depend on the composition of the organic material as anaerobic bacteria may not be able to decompose the complete suite of organic compounds [88].

Along the East Sumatra coastline, the land surface below $1 \mathrm{~m}+\mathrm{MSL}$ is currently below the common high tide level, usually covered by permanent swamps and mangroves in their natural state, and most land below $1.5 \mathrm{~m}+\mathrm{MSL}$ is already inundated much of the time. Peat deposits at these low elevations are, therefore, an unlikely source of future carbon emissions. When accounting for sea level rise, even a low estimate increase of $0.52 \mathrm{~m}$ by 2100 [89], will likely mean that only peat at elevations above $1.5 \mathrm{~m}$ or $2 \mathrm{~m}+\mathrm{MSL}$ will contribute substantially to future carbon emissions. The total volume of the deep peat carbon stock above the $1.5 \mathrm{~m}+\mathrm{MSL}$ reference level ranges between 7.2 and 9.3 Pg (Table 3) and this can be considered the most at risk.

\section{Past peat loss and the need to monitor peat thickness}

The map of thickness of deep peat provided in this study applies to 2017, when most of the airborne LiDAR data used for the underlying land surface elevation model (DTM) were collected [69]. However, continuous peat loss from oxidation resulting in land surface subsidence currently occurs in nearly all peatlands in Sumatra and Kalimantan, by rates varying from just below $2 \mathrm{~cm}$ year $^{-1}$ in forested peatland that is a few kilometres away from canals to over $4 \mathrm{~cm}_{\text {year }}{ }^{-1}$ in actively drained plantations with water levels lowered to an average of around $0.7 \mathrm{~m}$ below the peat surface $[29,90]$. Fires on peatland are a further source of subsidence by up to 0.3 or $0.5 \mathrm{~m}$ for a single event [36, 9193]. Over periods of 10 to 20 years, cumulative peat loss subsidence will therefore exceed $0.5 \mathrm{~m}$ in most remaining peatlands in the region.

The resulting uncertainty in peat extent and thickness created by ongoing peat loss is well illustrated for the Ogan Komering Ilir landscape in South Sumatra. The forest in this area was completely removed before 2000 [25], mostly in the 1980s [94], and subsequently drained for agriculture and forest plantations. A central peat dome is visible from the 2017 DTM (Fig. 10). However, where [56] mapped most of the area as peat, field surveys over 2013-2016 found only localized pockets of shallow peat in the low lying area outside of one remaining larger dome (Fig. 10). A combination of peat decomposition and repeated fires has resulted in peat loss, such that the land surface in most of the area is now below $2 \mathrm{~m}+\mathrm{MSL}$ (Fig. 10).

For practical applications peat thickness mapping should, in effect, be seen as peat thickness monitoring. For example, in areas where the peat surface is already low enough to cause flooding problems, regular updates of DTMs and associated peat thickness maps could be used to support flood risk assessment and land use planning decisions. Peat thickness monitoring can also provide information on carbon emissions caused by peat loss [29]. As any peat thickness map can, however, be outdated in a matter of years, the maps should be updated regularly, while accepting that the accuracy of peat thickness maps may never be very high in conditions where peat continues to be rapidly lost. Once an initial peat thickness map has been created from a DTM and sufficient peat thickness measurements have been obtained to estimate the peat bottom level, subsequent revised maps can be generated relatively easily from updates of the DTM.

\section{Deep peat areas and forest cover in eastern Sumatra}

Apart from a large below-ground carbon stock, in 2012 the deep peat areas also hosted nearly all (1.3 Mha or 93.6\%) of the remaining non mangrove forest in the DTM study area [86], as is illustrated in Fig. 11. In fact, large areas of intact forest remain on a few major peat domes (Fig. 11). Parts of these forested peat domes are formally protected and designated National Parks or Wildlife Reserves [59], but none are fully protected and all are under threat from logging and fires along their 


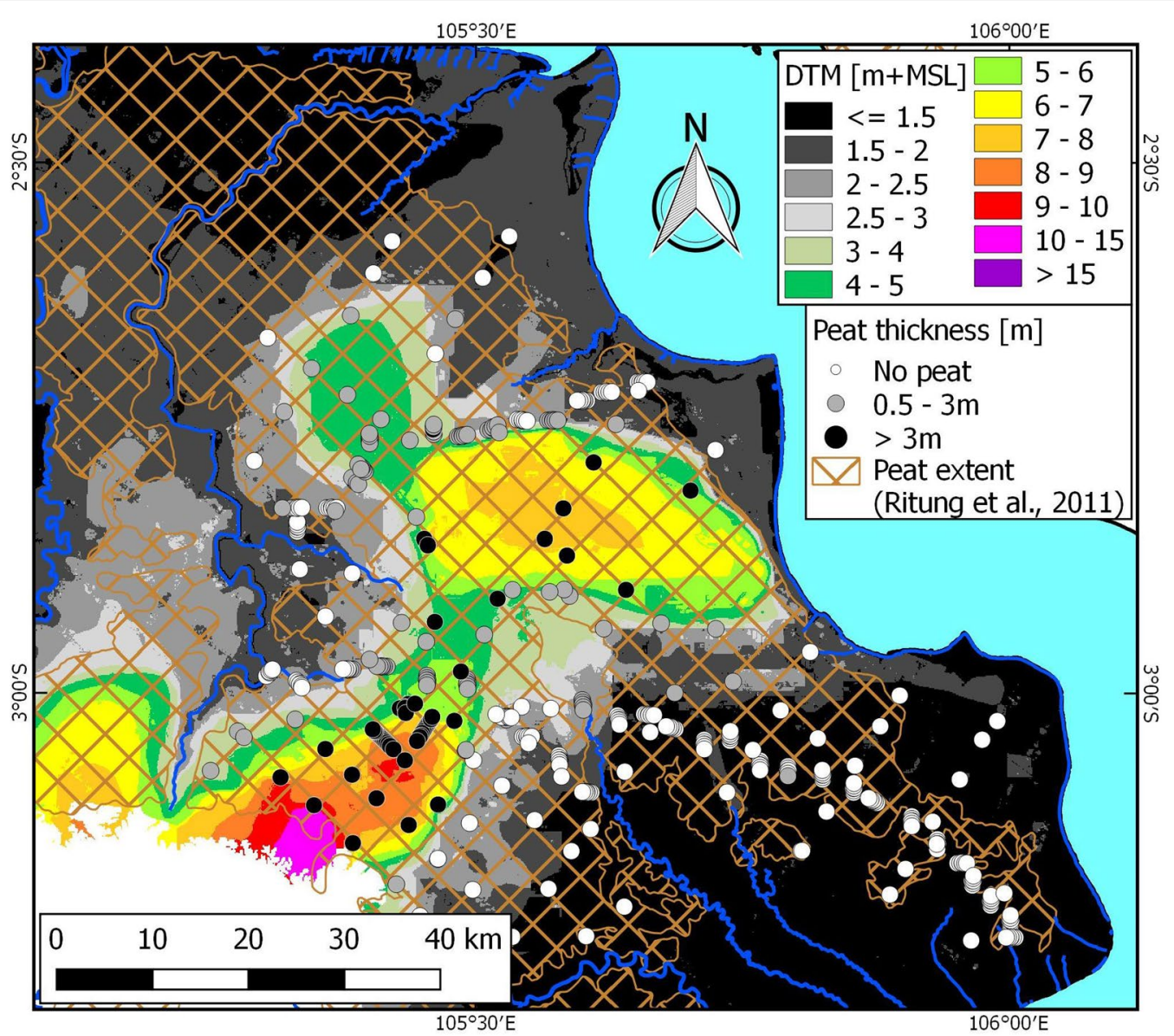

Fig. 10 Map of land surface elevation in the Eastern part of South Sumatra, and peat extent [56]. Grey dots indicate locations where peat thickness measured between 2013 and 2016 is less than $3 \mathrm{~m}$ and black dots greater than $3 \mathrm{~m}$. White dots are locations without peat

boundaries $[58,95]$. Protecting deep peat areas therefore currently still provides an opportunity to not only conserve large amounts of below-ground carbon stock, but also the last Sumatra lowland forest and associated high above-ground carbon stocks and unique biodiversity [96].

\section{Cost effective peat mapping using elevation models}

The deep peat map presented in this paper was generated using an elevation model derived from interpolated partial coverage airborne LiDAR data [69]. The associated cost of the airborne LiDAR data acquisition and processing was 1.5 USD per ha of actual LiDAR coverage [69], although substantially less for DTM coverage based on partial LiDAR coverage. For application at the very large scale of countries and regions, requiring coverage of tens of millions of hectares, this high cost is limiting progress in peat mapping. However high resolution elevation mapping is expected to rapidly become very cost effective with satellite LiDAR data from the Advanced
Topographic Laser Altimeter System (ATLAS) on board the Ice, Cloud and land Elevation Satellite (ICESat)-2 [97] and the Global Ecosystem Dynamics Investigation (GEDI) LiDAR attached to the International Space Station (ISS) $[98,99]$ being collected since late 2018 with the first data of the former available to the public by mid2019, without cost [97]. The potential of ICESat-1 data for measuring peat topography was earlier demonstrated by [100]. Our analysis of first ICESat- 2 data reveals peat dome shapes that are identical to the existing eastern Sumatra DTM used in this study as shown in Fig. 12. By late 2021, ICESat-2 data alone is targeted to provide nearglobal coverage (between $88^{\circ}$ north and south latitudes; [97]) of $\mathrm{N}-\mathrm{S}$ oriented flight lines at intervals of less than $2 \mathrm{~km}$ at the equator $[97,101]$, with GEDI expected to provide additional coverage with a spacing between tracks of about $\sim 600 \mathrm{~m}$ [99] between $51.6^{\circ}$ north and south latitudes [102]. This will allow creation of landscape DTMs as demonstrated by [69], that are suitable for rapid global mapping of peat domes applying the method presented 

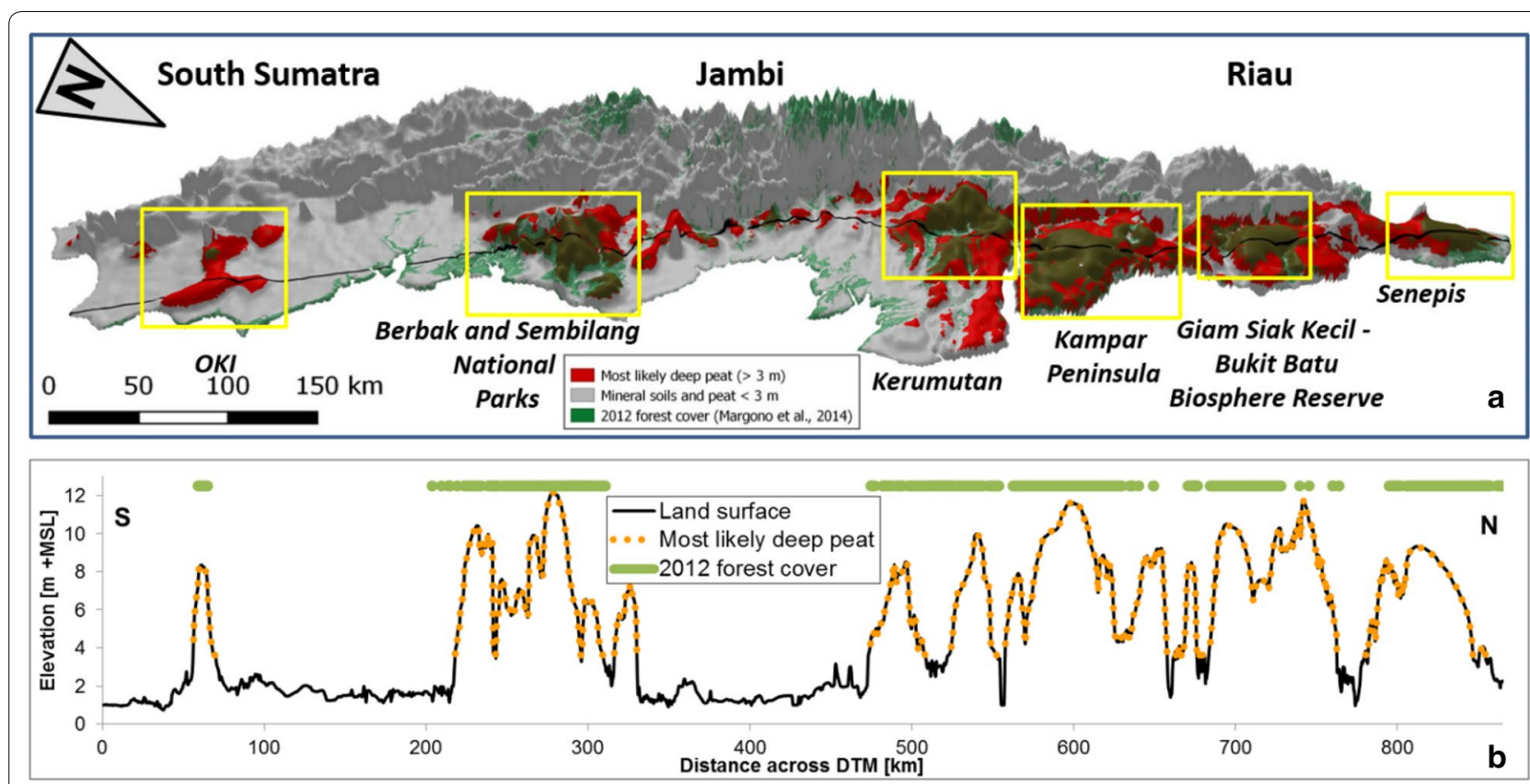

Fig. 11 a 3D model of eastern Sumatra DTM (Fig. 1) superimposed with the modelled deep peat areas and 2012 forest cover [86]. The airborne LiDAR based lowland DTM was merged with a SRTM based DTM for upland areas, to show the full landscape; elevations above $10 \mathrm{~m}+\mathrm{MSL}$ have sharply reduced vertical scale, by a factor 5 . Shown as well the location of surface elevation profile (black line) shown in (b) Surface elevation cross section along entire eastern Sumatra DTM, at approximately 20-70 km from the coastline. Most likely deep peat surface (>3 m) is shown assuming a peat bottom at $0.61 \mathrm{~m}+\mathrm{MSL}$. Indicated are the six major peat domes along the East Sumatra coast, from North to South: Senepis, Giam Siak Kecil—Bukit Batu Biosphere Reserve, Kampar Peninsula, Kerumutan in Riau, Berbak and Sembilang National Parks in Jambi and South Sumatra and OKI in South Sumatra Province. Note that the peat swamp forest on Kampar Peninsula and Senepis are not formally protected

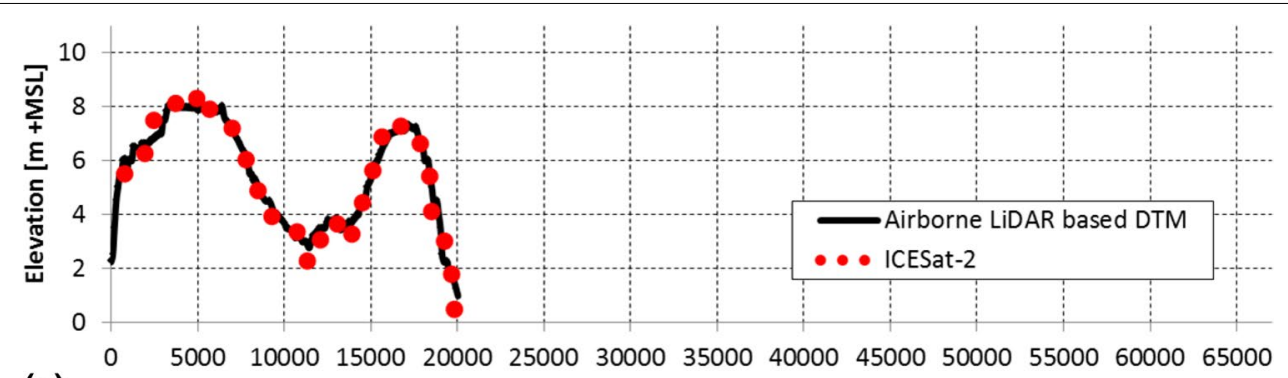

(a) Distance across peat domes, from coast [m] (North to South)

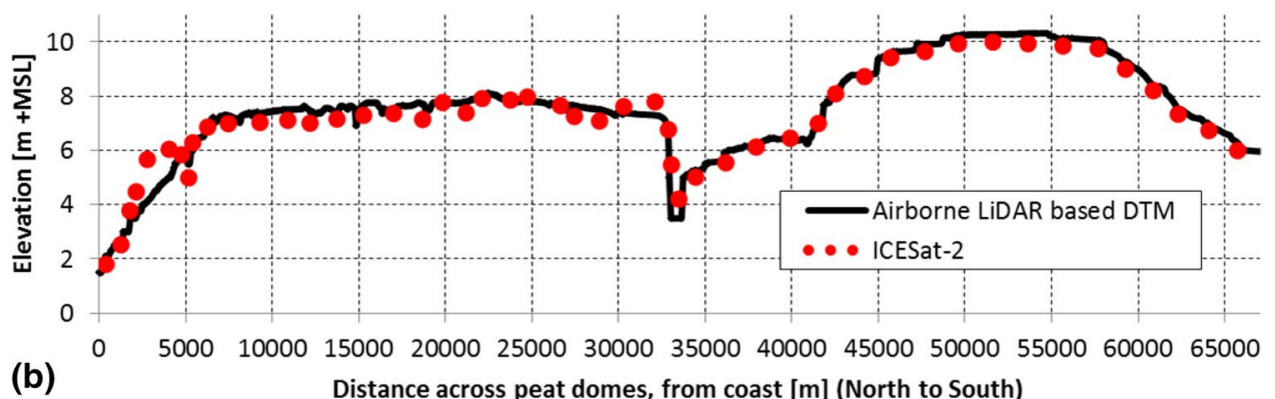

Fig. 12 Cross section over a Bengkalis Island and $\mathbf{b}$ the Giam Siak Kecil—Bukit Batu Biosphere Reserve covering peat domes along ICESat-2 flight lines, showing airborne LiDAR derived surface elevation (DTM; [69] and ICESat-2 terrain height. As current raw ICESat-2 data is referenced to the ellipsoid and requires vertical correction, it was provisionally referenced to mean sea level (MSL) by matching it to the DTM. Location of the cross sections is shown for $\mathbf{a}$ in Fig. 4 and $\mathbf{b}$ in Fig. 1 
in this paper, and thereby improving estimates of regional and global peat carbon stocks and their vulnerability.

\section{Conclusions and recommendations}

This paper demonstrates that it is possible to create a peat thickness map that is suitable for the purposes of land use zoning and carbon stock calculations from a LiDAR-derived DTM and with limited peat thickness field measurements, in raised bog type peatland with relatively uniform peat bottom elevation. In areas where the peat bottom is more variable, or in conditions where accuracy requirements are very high, more peat thickness measurements can be added stepwise until certain accuracy criteria are met. However, where the peat bottom is around or below $1.5 \mathrm{~m}+\mathrm{MSL}$ in SE Asian lowlands, it may be considered whether high accuracy in peat thickness mapping is required as this peat is expected to be permanently below the water table due to sea level rise. These low-lying peatlands may not, therefore, generate substantial carbon emissions in the future, albeit we note the potential for a positive carbon feedback to the atmosphere from inundated coastal peatlands [87].

We believe that the map of deep peat in eastern Sumatra presented in this study can make a contribution to broader approaches to peat mapping in Indonesia. Where higher accuracy is required, the map may be refined by collecting additional data. Mapping shallow peat areas will require more ground data or possibly geophysical methods, such as ground-penetrating radar (GPR) and electrical resistivity imaging [103], although it is noted that GPR also has its limitations when saline groundwater is present in shallow aquifers of coastal peatlands, because saline water attenuates GPR signals [104]. Both the DTM [69] and the deep peat map used in this analysis are available in the public domain from (https://doi. org/10.17632/c83z4df8ky.1) to be used in application and further analysis.

By focusing on remaining deep peat in SE Asia, much of which is still forested, it will be easier to define and implement strategies to protect the remaining peatland. The deep peat carbon stock range of 9.0-11.5 Pg above the $0.61 \mathrm{~m}+\mathrm{MSL}$ average peat bottom reference level in the eastern Sumatra study area alone, represents 8.6$11.0 \%$ of the $104.7 \mathrm{Pg}$ global tropical peat carbon stock $[2,21]$, in a relatively small land area of 2.6 Mha that is the equivalent of Belgium or Wales. We propose that in the SE Asian context, prioritizing the protection of deep peat areas and associated forest could result in the best conservation outcomes both in terms of reduced carbon emissions and the safeguarding of forest and biodiversity. Nevertheless, ongoing peat loss resulting from the rapid pace of land use change (scale and intensity) and the regular occurrence of fires across the whole of the SE Asian region will necessitate regular updating of peat maps to ensure that they remain relevant.

The peat mapping method described here is applicable to any peatland that has a somewhat flat peat bottom. This includes some 'raised bogs' located in shallow basins and found in coastal lowlands and alluvial plains throughout continental Eurasia and North America, but could also extend to peatlands in the Congo and Amazon river basins as well, although knowledge of the morphology of these peatlands is still under investigation [105]. The method would exclude peatlands formed in deep basins (e.g. in kettle holes) as well as most upland northern peat deposits that tend to be 'blanket bogs' that follow a pre-existing landscape. We therefore propose rapid application of this method using satellite LiDAR data, complemented with airborne LiDAR where available, to other 'raised bog' peatlands globally that require improved peatland mapping.

\section{Abbreviations}

ATLAS: Advanced Topographic Laser Altimeter System; BD: Bulk density; CC: Carbon concentration; DTM: Digital Terrain Model; GEDI: Global Ecosystem Dynamics Investigation; ICESat: Ice, Cloud and land Elevation Satellite; IPP: Indonesian Peat Prize; LiDAR: Light Detection and Ranging; MSL: Mean sea level; PB: Peat bottom; PT: Peat thickness.

\section{Acknowledgements}

The Bengkalis and Kubu Raya validation parts of this study were included in the Deltares and ITB submission to the Indonesian Peat Prize (IPP) competition hosted by the Indonesian Geospatial Information Agency (BIG). Part of the peat thickness measurements used in the creation of the eastern Sumatra deep peat map were collected as part of the Quick Assessment and Nationwide Screening (QANS) of Peat and Lowland Resources and Action Planning for the Implementation of a National Lowland Strategy project hosted by the Indonesian Ministry of National Development Planning (Bappenas). We wish to thank the anonymous reviewers for their constructive and useful comments and suggestions that enabled us to improve the content of this paper.

\section{Authors' contributions}

$\mathrm{RV}, \mathrm{AH}, \mathrm{ATY}$ and DM conceived the research. RV, AH, RA, NF, HA and DM designed the field surveys. RA, NF, and DM carried out the field work. RV, $\mathrm{AH}, \mathrm{RA}, \mathrm{NF}$ and ATY analysed the data. RV, AH, ATY, HA and SP co-wrote the first draft of the manuscript, which was edited by all authors. All the authors contributed to the discussion of the results. All authors read and approved the final manuscript.

\section{Funding}

The peat mapping work for eastern Sumatra and West Kalimantan was supported by APP (Asia Pulp and Paper), United Kingdom Climate Change Unit, and Norwegian Agency for Development Cooperation.

\section{Availability of data and materials}

The DTM (https://doi.org/10.17632/72r3bvdd3r.1) and the deep peat map (https://doi.org/10.17632/c83z4df8ky.1) used in this analysis are available in Mendeley.

\section{Ethics approval and consent to participate}

Not applicable.

Consent for publication

Not applicable. 


\section{Competing interests}

SEP was a member of the scientific advisory board for the IPP competition but only joined the author team for this paper after the IPP competition had concluded. The other authors declare no competing interests.

\section{Author details}

${ }^{1}$ Inland Water Systems Unit, Deltares, P.O. Box 177, 2600 MH Delft, The Netherlands. ${ }^{2}$ Present Address: Data for Sustainability, 4571 AK Axel, The Netherlands. ${ }^{3}$ PT Alas Rawa Khatulistiwa, Jakarta, Indonesia. ${ }^{4}$ Geodesy Research Group, Institute of Technology Bandung (ITB), J. Ganesha 10, Bandung, Indonesia. ${ }^{5}$ Centre for Landscape and Climate Research, School of Geography, Geology and the Environment, University of Leicester, Leicester LE1 7RH, UK.

Received: 26 July 2019 Accepted: 6 March 2020

Published online: 23 March 2020

\section{References}

1. Hooijer A, Page S, Canadell JG, Silvius M, Kwadijk J, Wösten H, et al. Current and future $\mathrm{CO}_{2}$ emissions from drained peatlands in Southeast Asia. Biogeosciences. 2010;7:1505-14.

2. Page SE, Rieley JO, Banks CJ. Global and regional importance of the tropical peatland carbon pool. Glob Change Biol. 2011;17:798-818.

3. Miettinen J, Hooijer A, Vernimmen R, Liew SC, Page SE. From carbon sink to carbon source: extensive peat oxidation in insular Southeast Asia since 1990. Environ Res Lett. 2017;12:024014.

4. Gaveau DLA, Salim MA, Hergoualc'h K, Locatelli B, Sloan S, Wooster M, et al. Major atmospheric emissions from peat fires in Southeast Asia during non-drought years: evidence from the 2013 Sumatran fires. Sci Rep. 2014:4:6112.

5. Huijnen V, Wooster MJ, Kaiser JW, Gaveau DLA, Flemming J, Parrington $M$, et al. Fire carbon emissions over maritime southeast Asia in 2015 largest since 1997. Sci Rep. 2016;6:26886.

6. Giam X, Koh LP, Tan HH, Miettinen J, Tan HT, Ng PK. Global extinctions of freshwater fishes follow peatland conversion in Sundaland. Front Ecol Environ. 2012;10:465-70.

7. Wibisono HT, Linkie M, Guillera-Arroita G, Smith JA, Sunarto, Pusparini W, et al. Population status of a cryptic top predator: an island-wide assessment of tigers in Sumatran rainforests. PLOS ONE. 2011;6:e25931.

8. Posa MRC. Peat swamp forest avifauna of Central Kalimantan, Indonesia: effects of habitat loss and degradation. Biol Conserv. 2011;144:2548-56.

9. Morrogh-Bernard H, Husson S, Page SE, Rieley JO. Population status of the Bornean orang-utan (Pongo pygmaeus) in the Sebangau peat swamp forest, Central Kalimantan, Indonesia. Biol Conserv. 2003;110:141-52.

10. Hooijer A, Vernimmen R, Visser M, Mawdsley N. Flooding projections from elevation and subsidence models for oil palm plantations in the Rajang Delta peatlands, Sarawak, Malaysia. Deltares report 1207384, 76 pp. 2015. https://www.deltares.nl/app/uploads/2015/06/Rajan g-Delta-Peatland-Subsidence-Flooding-Deltares-2015.pdf. Accessed 17 July 2019.

11. Hooijer A, Vernimmen R, Mawdsley N, Page S, Mulyadi D, Visser M Assessment of impacts of plantation drainage on the Kampar Peninsula peatland, Riau. Deltares Report 1207384 to Wetlands International, CLUA and Norad. 2015. https://www.deltares.nl/app/uploads/2015/12/ Plantation-Impacts-Kampar-Peatland-DELTARES-2015.pdf. Accessed 17 July 2019.

12. Sumarga E, Hein L, Hooijer A, Vernimmen R. Hydrological and economic effects of oil palm cultivation in Indonesian peatlands. Ecol Soc. 2016;21:art52.

13. Hodgkins SB, Richardson CJ, Dommain R, Wang H, Glaser PH, Verbeke $B$, et al. Tropical peatland carbon storage linked to global latitudinal trends in peat recalcitrance. Nat Commun. 2018:9:3640.

14. Leifeld J, Menichetti L. The underappreciated potential of peatlands in global climate change mitigation strategies. Nat Commun. 2018;9:1071

15. Immirzi CP, Maltby E, Clymo R. The global status of peatlands and their role in carbon cycling: a report for Friends of the Earth. June 1992 London; 1992.

16. Clymo RS. The limits to peat bog growth. Phil Trans R Soc B Biol Sci. 1984:303:605-54
17. Treat CC, Wollheim WM, Varner RK, Grandy AS, Talbot J, Frolking S. Temperature and peat type control $\mathrm{CO}_{2}$ and $\mathrm{CH}_{4}$ production in Alaskan permafrost peats. Glob Change Biol. 2014;20:2674-86.

18. Chimner RA, Ewel KC. A tropical freshwater wetland: II. Production, decomposition, and peat formation. Wetlands Ecol Manage. 2005; 13:671-84

19. Yule CM. Loss of biodiversity and ecosystem functioning in IndoMalayan peat swamp forests. Biodivers Conserv. 2010;19:393-409.

20. Couwenberg J, Dommain R, Joosten H. Greenhouse gas fluxes from tropical peatlands in south-east Asia. Glob Change Biol. 2010;16:1715-32.

21. Dargie GC, Lewis SL, Lawson IT, Mitchard ETA, Page SE, Bocko YE, et al. Age, extent and carbon storage of the central Congo Basin peatland complex. Nature. 2017;542:86-90.

22. Lähteenoja O, Reátegui YR, Räsänen M, Torres DDC, Oinonen M, Page S. The large Amazonian peatland carbon sink in the subsiding PastazaMarañón foreland basin, Peru. Glob Change Biol. 2012;18:164-78.

23. Draper FC, Roucoux KH, Lawson IT, Mitchard ETA, Honorio Coronado EN, Lähteenoja $\mathrm{O}$, et al. The distribution and amount of carbon in the largest peatland complex in Amazonia. Environ Res Lett. 2014;9:124017.

24. Gumbricht T, Roman-Cuesta RM, Verchot L, Herold M, Wittmann F, Householder E, et al. An expert system model for mapping tropical wetlands and peatlands reveals South America as the largest contributor. Glob Change Biol. 2017;23:3581-99.

25. Jaenicke J, Rieley JO, Mott C, Kimman P, Siegert F. Determination of the amount of carbon stored in Indonesian peatlands. Geoderma. 2008;147:151-8.

26. Warren M, Hergoualc'h K, Kauffman JB, Murdiyarso D, Kolka R. An appraisal of Indonesia's immense peat carbon stock using national peatland maps: uncertainties and potential losses from conversion. Carbon Balance Manage. 2017;12:12

27. Warren MW, Kauffman JB, Murdiyarso D, Anshari G, Hergoualc'h K, Kurnianto S, et al. A cost-efficient method to assess carbon stocks in tropical peat soil. Biogeosciences. 2012;9:4477-85.

28. Dommain R, Cobb AR, Joosten H, Glaser PH, Chua AFL, Gandois L, et al. Forest dynamics and tip-up pools drive pulses of high carbon accumulation rates in a tropical peat dome in Borneo (Southeast Asia): carbon accumulation in tip-up pools. J Geophys Res Biogeosci. 2015;120:617-40

29. Hooijer A, Page S, Jauhiainen J, Lee WA, Lu XX, Idris A, et al. Subsidence and carbon loss in drained tropical peatlands. Biogeosciences. 2012:9:1053-71.

30. Fowler G. Shrinkage of the peat-covered fenlands. Geogr J. 1933;81:149-50.

31. Galloway D, Jones D, Ingebritsen S. Land Subsidence in the United States. U.S. Geological Survey Circular 1182. 1999. http://pubs.usgs.gov/ circ/circ1182/.

32. Hutchinson J. The record of peat wastage in the East Anglian Fenlands at Holme Post, 1848-1978 AD. J Ecol. 1980;68:229-49.

33. Stephens JC, Allen LH, Chen E. Organic soil subsidence. Reviews in Engineering Geology. Geological Society of America; 1984. p. 107-22. https://pubs.geoscienceworld.org/books/book/831/chapter/4851116/. Accessed 25 July 2019.

34. Prokopovich NP. Subsidence of peat in California and Florida. Environ Eng Geosci. 1985:22:395-420.

35. Lindsay R, Birnie R, Clough J. Impacts of artificial drainage on peatlands. IUCN UK Committee Peatland Programme. Briefing Note No. 3. 2014. http://www.iucn-uk-peatlandprogramme.org. Accessed 17 July 2019.

36. Page SE, Siegert F, Rieley JO, Boehm H-DV, Jaya A, Limin S. The amount of carbon released from peat and forest fires in Indonesia during 1997. Nature. 2002;420:61-5.

37. Deverel SJ, Rojstaczer S. Subsidence of agricultural lands in the Sacramento-San Joaquin Delta, California: role of aqueous and gaseous carbon fluxes. Water Resour Res. 1996:32:2359-67.

38. Deverel SJ, Leighton DA. Historic, recent, and future subsidence, Sacramento-San Joaquin Delta, California, USA. SFEWS. 2010;8. http:// escholarship.org/uc/item/7xd4x0xw. Accessed 19 July 2019.

39. Brady M. Organic matter dynamics of coastal peat deposits in Sumatra, Indonesia. [Ph.D]. The University of British Columbia, Canada; 1997. 
40. Gambolati G, Putti M, Teatini P, Gasparetto Stori G. Subsidence due to peat oxidation and impact on drainage infrastructures in a farmland catchment south of the Venice Lagoon. Environ Geol. 2006;49:814-20.

41. Erkens G, van der Meulen MJ, Middelkoop H. Double trouble: subsidence and $\mathrm{CO}_{2}$ respiration due to 1,000 years of Dutch coastal peatlands cultivation. Hydrogeol J. 2016;24:551-68.

42. Rieley J, Page S. Wise use of tropical peatlands: focus of Southeast Asia. Wageningen: ALTERRA Wageningen University and Research Centre and the EU INCO-STRAPEAT and RESTORPEAT Partnership; 2005.

43. Corlett R. The ecology of tropical East Asia. New York: Oxford University Press; 2009

44. Suhardjo H, Driessen P. Reclamation and use of Indonesian lowland peats and their effects on soil conditions. In: Proceedings of the third ASEAN soil conference, Kuala Lumpur, Malaysia, 26 November-5 December 1975. Kuala Lumpur, Malaysia; 1975. p. 419-24.

45. Notohadiprawiro T, Sukana E, Dradjad M. Present status of knowledge about soils of estuarines and their utilization for permanent agriculture, with special reference to Kalimantan. In: Proceedings Simposium Nasional III Pengembangan Daerah Pasang Surut di Indonesia. 1979. p. 656-96.

46. Notohadiprawiro T. Tanah Estuarin. Jakarta: Ghalia Indonesia; 1986

47. Miettinen J, Shi C, Liew SC. Land cover distribution in the peatlands of Peninsular Malaysia, Sumatra and Borneo in 2015 with changes since 1990. Glob Ecol Conserv. 2016;6:67-78.

48. World Bank. The cost of fire: an economic analysis of Indonesia's 2015 fire crisis. 2016. http://documents.worldbank.org/curated/en/77610 1467990969768/pdf/103668-BRI-Cost-of-Fires-Knowledge-Note-PUBL C-ADD-NEW-SERIES-Indonesia-Sustainable-Landscapes-KnowledgeNote.pdf. Accessed 17 July 2019.

49. Lohberger S, Stängel M, Atwood EC, Siegert F. Spatial evaluation of Indonesia's 2015 fire-affected area and estimated carbon emissions using Sentinel-1. Glob Change Biol. 2018;24:644-54.

50. BRG. Mengawali Restorasi Gambut Indonesia. Annual report. Jakarta: Badan Restorasi Gambut. 2016. https://brg.go.id/files/Publikasi/BRG\%20 2016\%20report_29.05.17.pdf. Accessed 17 July 2019.

51. Hooijer A, Vernimmen R. Peatland maps for Indonesia. Including accuracy assessment and recommendations for improvement, elevation mapping and evaluation of future flood risk. Quick Assessment and Nationwide Screening (QANS) of Peat and Lowland Resources and Action Planning for the Implementation of a National Lowland Strategy_PVW3A10002. Agentschap NL 6201068 QANS Lowland Development, for Government of Indonesia and Partners for Water (Netherlands). 2013. https://www.deltares.nl/app/uploads/2015/03/ QANS-Peat-mapping-report-final-with-cover.pdf. Accessed 17 July 2019

52. Mongabay. 2018. https://news.mongabay.com/2018/02/scientists -from-indonesia-germany-and-the-netherlands-win-indonesian-peatprize/. Accessed 17 July 2019.

53. Dohong A, Aziz AA, Dargusch P. Carbon emissions from oil palm development on deep peat soil in Central Kalimantan Indonesia. Anthropocene. 2018;22:31-9.

54. Dommain R, Couwenberg J, Glaser PH, Joosten H, Suryadiputra INN. Carbon storage and release in Indonesian peatlands since the last deglaciation. Quatern Sci Rev. 2014;97:1-32.

55. Osaki M, Nursyamsi D, Noor M, Wahyunto, Segah H. Peatland in Indonesia. In: Osaki M, Tsuji N, editors. Tropical peatland ecosystems. Tokyo: Springer Japan; 2016. p. 49-58. https://doi.org/10.1007/978-4-43155681-7_3.

56. Ritung S, Wahyunto, Nugroho K, Sukarman, Hikmatullah, Suparto, et al. Peta lahan gambut Indonesia. Skala 1:250.000 (Indonesian peatland map at the scale 1:250,000). Balai Besar Penelitian dan Pengembangan Sumberdaya Lahan Pertanian (Indonesian Center for Agricultural Land Resources Research and Development), Bogor, Indonesia. 2011.

57. Miettinen J, Hooijer A, Shi C, Tollenaar D, Vernimmen R, Liew SC, et al. Extent of industrial plantations on Southeast Asian peatlands in 2010 with analysis of historical expansion and future projections. Glob Change Biol Bioenergy. 2012;4:908-18

58. Miettinen J, Shi C, Liew SC. Deforestation rates in insular Southeast Asia between 2000 and 2010. Glob Change Biol. 2011;17:2261-70.
59. UNEP-WCMC Protected area profile for Indonesia from the World Database of Protected Areas, April 2019. 2019. http://www.protectedp lanet.net. Accessed 17 July 2019.

60. Wijedasa LS, Vernimmen R, Page SE, Mulyadi D, Bahri S, Randi A, et al. Distance to forest, mammal and bird dispersal drive natural regeneration on degraded tropical peatland. For Ecol Manage. 2020;461:117868.

61. Wilmar International. No deforestation, no peat, no exploitation policy. 2013. https://www.wilmar-international.com/wp-content/uploa ds/2012/11/No-Deforestation-No-Peat-No-Exploitation-Policy.pdf. Accessed 17 July 2019.

62. GAR. Sustainability report 2012. 2012. https://goldenagri.com.sg/wpcontent/uploads/2016/01/GAR-Sustainability_FINAL.pdf. Accessed 17 July 2019.

63. GAR. Forest Conservation Policy. 2014. https://goldenagri.com.sg/ wp-content/uploads/2016/01/1._GAR_Forest_Conservation_Polic y_- updated links 10 Jan_2014.pdf. Accessed 17 July 2019.

64. APP. APP Forest conservation policy update. 2014. https://asiapulppa per.com/system/files/18_month_fcp_update_final1.pdf. Accessed 17 July 2019.

65. APRIL. APRIL Group's sustainable forest management policy 2.0. 2015. http://www.aprilasia.com/id/images/pdf_files/april-sfmp2-3-june-2015. pdf. Accessed 17 July 2019.

66. Cargill Inc. Cargill Policy on sustainable palm oil. 2014. https://www. cargill.com/doc/1432076149492/palm-oil-policy-statement-pdf.pdf. Accessed 17 July 2019.

67. Mongabay. 2015. https://news.mongabay.com/2015/11/jokowi-tooversee-indonesia-peat-restoration-agency-but-details-thin-on-theground-2/. Accessed 17 July 2019.

68. Government of Indonesia. Establishment of Peat Restoration Agency. Presidential Decree No. 1/2016. 2016.

69. Vernimmen R, Hooijer A, Yuherdha AT, Visser M, Pronk M, Eilander D, et al. Creating a Lowland and Peatland Landscape Digital Terrain Model (DTM) from Interpolated Partial Coverage LiDAR Data for Central Kalimantan and East Sumatra, Indonesia. Remote Sens. 2019;11:1152.

70. Vernimmen R, Akmalia R, Fitranatanegara N, Artiyan E, Febrianto T, Yuherdha A, et al. Peatland mapping for Kubu Raya, West Kalimantan, using limited LiDAR data and peat thickness field measurements. Team Deltares report to the Indonesian Peat Prize-final phase. 2018. https ://www.deltares.nl/app/uploads/2019/04/Peatland-mapping-for-KubuRaya-Team-Deltares.pdf. Accessed 17 July 2019.

71. Vernimmen R, Hooijer A, Akmalia R, Mulyadi D, Syahrozi O, Anugrah I, et al. Peatland mapping for Bengkalis Island, Riau, using limited LiDAR data and peat thickness field measurements. Team Deltares report to the Indonesian Peat Prize_-Solution Development Phase. 2017. https ://www.deltares.nl/app/uploads/2019/04/Peatland-mapping-for-Bengk alis-Island-Team-Deltares.pdf. Accessed 17 July 2019.

72. Staub JR, Esterle JS. Peat-accumulating depositional systems of Sarawak, East Malaysia. Sediment Geol. 1994;89:91-106.

73. Page SE, Rieley JO, Wüst R. Chapter 7 Lowland tropical peatlands of Southeast Asia. Developments in earth surface processes. Amsterdam: Elsevier; 2006. p. 145-72.

74. Hooijer A. Hydrology of tropical wetland forests: recent research results from Sarawak peatswamps. In: Bonell M, Bruijnzeel LA, editors. Forests, water and people in the humid tropics. Cambridge: Cambridge University Press; 2005. p. 447-61. https://www.cambridge.org/core/product/ identifier/CBO9780511535666A030/type/book_part. Accessed 19 July 2019.

75. Anderson J. The structure and development of peat swamps of Sarawak and Brunei. J Trop Geogr. 1964;18:7-16.

76. Cameron CC, Esterle JS, Palmer CA. The geology, botany and chemistry of selected peat-forming environments from temperate and tropical latitudes. Int J Coal Geol. 1989;12:105-56.

77. Esterle J, Calvert G, Durig D, Tie Y, Supardi. Characterization and classification of tropical woody peats from Baram River Area, Sarawak and Jambi, Sumatra. In: Aminuddin B, editor. Proceedings of the MARDI symposium on tropical peat and peatlands, Kuching, Sarawak, Malaysia, 6-10 May 1991. Kuching, Sarawak, Malaysia; 1991. p. 33-48.

78. Tie Y, Esterle J. Formation of lowland peat domes in Sarawak, Malaysia. In: Aminuddin B, editor. Proceedings of the MARDI symposium on tropical peat and peatlands, Kuching, Sarawak, Malaysia, 6-10 May 1991. Kuching, Sarawak, Malaysia; 1991. p. 81-9. 
79. Staub J, Gastaldo R. Late quaternary sedimentation and peat development in the Rajang river delta, Sarawak, East Malaysia. In: Sidi FH, Nummedal D, Imbert P, Darman H, Posamentier HW, editors. Tropical deltas of Southeast Asia. SEPM (Society for Sedimentary Geology); 2003. p. 71-87. http://sp.sepmonline.org/content/sepspecpub/sepsptro/1. toccontent/76. Accessed 25 July 2019.

80. Ritzema H, Wösten H. Hydrology of Borneo's peat swamps. STRAPEAT status report. Alterra: Wageningen; 2002.

81. Melling L, Hatano R. Peat soils study of the peat swamp in the Maludam National Park, Betong Division, Sarawak. Joint Working Group Malaysia-The Netherlands. Development and Management of Maludam National Park. Alterra, Wageningen, The Netherlands. Malaysia, Sarawak; 2004.

82. Sayok A, Nik A, Melling L, Samad R, Efransjah E. Some characteristics of peat in Loagan Bunut National Park, Sarawak, Malaysia. In: Carbopeat Conference proceedings. Yogyakarta; 2008. p. 7.

83. Flores RM. Origin of coal as gas source and reservoir rocks. In: Coal and coalbed gas. Amsterdam: Elsevier; 2014. p. 97-165.

84. Supardi, Subekty A, Neuzil S. General geology and peat resources of the Siak Kanan and Bengkalis Island peat deposits, Sumatra, Indonesia. Geological Society of America Special Papers. Geological Society of America. 1993. p. 45-62. https://pubs.geoscienceworld.org/books/ book/425/chapter/3798499/. Accessed 19 July 2019.

85. Cecil CB, Dulong FT, Cobb JC. Allogenic and autogenic controls on sedimentation in the central Sumatra basin as an analogue for Pennsylvanian coal-bearing strata in the Appalachian basin. Geological Society of America Special Papers. Geological Society of America; 1993. p. 3-22. https://pubs.geoscienceworld.org/books/book/425/chapter/3798491/. Accessed 25 July 2019

86. Margono BA, Potapov PV, Turubanova S, Stolle F, Hansen MC. Primary forest cover loss in Indonesia over 2000-2012. Nat Clim Change. 2014;4:730-5

87. Henman J, Poulter B. Inundation of freshwater peatlands by sea level rise: uncertainty and potential carbon cycle feedbacks: carbon emissions from sea level rise. J Geophys Res. 2008;113:n/a-n/a.

88. Canfield DE. Sulfate reduction and oxic respiration in marine sediments: implications for organic carbon preservation in euxinic environments. Deep Sea Res Part A Oceanogr Res Pap. 1989;36:121-38.

89. Jevrejeva S, Jackson LP, Grinsted A, Lincke D, Marzeion B. Flood damage costs under the sea level rise with warming of $1.5^{\circ} \mathrm{C}$ and $2{ }^{\circ} \mathrm{C}$. Environ Res Lett. 2018;13:074014.

90. Evans CD, Williamson JM, Kacaribu F, Irawan D, Suardiwerianto $Y$, Hidayat MF, et al. Rates and spatial variability of peat subsidence in Acacia plantation and forest landscapes in Sumatra, Indonesia. Geoderma. 2019;338:410-21.

91. Simpson J, Wooster M, Smith T, Trivedi M, Vernimmen R, Dedi R, et al Tropical peatland burn depth and combustion heterogeneity assessed using UAV photogrammetry and airborne LiDAR. Remote Sens. 2016;8:1000.

92. Ballhorn U, Siegert F, Mason M, Limin S. Derivation of burn scar depths and estimation of carbon emissions with LIDAR in Indonesian peatlands. PNAS. 2009;106:21213-8.

93. Konecny K, Ballhorn U, Navratil P, Jubanski J, Page SE, Tansey K, et al. Variable carbon losses from recurrent fires in drained tropical peatlands. Glob Change Biol. 2016;22:1469-80.
94. Caufield C. Indonesia's great exodus. New Scientist. 1984 May 17. https://books.google.nl/books?id=rlKOqp_hyccC $\& p g=P A 26 \& l p g=P A 26 \& d q=$ sugihan + peat+new+scientist \&sourc $\mathrm{e}=\mathrm{bl} \& \mathrm{ots}=\mathrm{hi}$ ZECXN7R\&sig =ACfU3U2y2bVSdZ1 xuzHkTNcC6eu6Vx s25g\&hl=en\&sa $=$ X\&ved $=$ 2ahUKEwi6y900kcPhAhVOZIAKHfenC _4Q6AEwAnoECAkQAQ\#v=onepage\&q=sugihan\%20peat\%20new \%20scientist\&f=false. Accessed 17 July 2019.

95. Miettinen J, Wang J, Hooijer A, Liew S. Peatland conversion and degradation processes in insular southeast Asia: a case study in Jambi, Indonesia: peatland conversion and degradation in southeast asia. Land Degrad Dev. 2011;24:334-41.

96. Laumonier Y. The vegetation and physiography of Sumatra. Dordrecht: Springer Netherlands; 1997. https://doi.org/10.1007/978-94-009-0031-8.

97. Neuenschwander A, Pitts K. The ATL08 land and vegetation product for the ICESat-2 mission. Remote Sens Environ. 2019;221:247-59.

98. Stysley PR, Coyle DB, Clarke GB, Frese E, Blalock G, Morey P, et al. Laser production for NASA's Global Ecosystem Dynamics Investigation (GEDI) lidar. In: Turner MD, Kamerman GW, editors. Baltimore. 2016. p. 983207. http://proceedings.spiedigitallibrary.org/proceeding aspx?doi=10.1117/12.2239889. Accessed 22 July 2019

99. Stavros EN, Schimel D, Pavlick R, Serbin S, Swann A, Duncanson L, et al. ISS observations offer insights into plant function. Nat Ecol Evol. 2017;1:0194.

100. Ballhorn U, Jubanski J, Siegert F. ICESat/GLAS data as a measurement tool for peatland topography and peat swamp forest biomass in Kalimantan, Indonesia. Remote Sens. 2011;3:1957-82.

101. Markus T, Neumann T, Martino A, Abdalati W, Brunt K, Csatho B, et al. The Ice, Cloud, and land Elevation Satellite-2 (ICESat-2): science requirements, concept, and implementation. Remote Sens Environ. 2017;190:260-73.

102. Patterson PL, Healey SP, Ståhl G, Saarela S, Holm S, Andersen H-E, et al. Statistical properties of hybrid estimators proposed for GEDINASA's global ecosystem dynamics investigation. Environ Res Lett. 2019;14:065007.

103. Comas X, Terry N, Slater L, Warren M, Kolka R, Kristiyono A, et al. Imaging tropical peatlands in Indonesia using ground-penetrating radar (GPR) and electrical resistivity imaging (ERI): implications for carbon stock estimates and peat soil characterization. Biogeosciences. 2015;12:2995-3007

104. Robinson M, Bristow C, McKinley J, Ruffell A. Ground Penetrating Radar. In: Cook S, Clarke L, Neild J, editors. Geomorphological techniques. London: British Society for Geomorphology; 2013.

105. Davenport I, McNicol I, Hawthorne D, Mitchard E, Lewis S, Dargie G, et al. UAV and Spaceborne LiDAR gives first evidence of peat domes in the Congo Basin. Remote Sens. (submitted).

\section{Publisher's Note}

Springer Nature remains neutral with regard to jurisdictional claims in published maps and institutional affiliations.

Ready to submit your research? Choose BMC and benefit from

- fast, convenient online submission

- thorough peer review by experienced researchers in your field

- rapid publication on acceptance

- support for research data, including large and complex data types

- gold Open Access which fosters wider collaboration and increased citations

- maximum visibility for your research: over 100M website views per year

At BMC, research is always in progress.

Learn more biomedcentral.com/submissions 